\title{
A critical review on the plants used for the treatment of ulcer in Kerala
}

\author{
Original \\ Article \\ Jincy J., Nancy J., Jipnomon J. \\ Department of Pharmacology, St. Joseph's College of Pharmacy, Cherthala, Kerala, India.
}

\begin{abstract}
Peptic ulcer disease and its complications remain the cause of significant morbidity worldwide, representing a major burden for health care resources. Although potent anti-ulcer drugs are available, most of them produce several toxicities, thus emphasizing the need to search for new alternatives. As high as $80 \%$ of the world population depends on plantderived medicines for the first line of primary health care, reinforcing the theory that plant extracts can be good sources of new drugs. This review focuses to consolidate the evidence-based information on antiulcer plants used in Kerala accumulated in databases (Google Scholar, PubMed, Scopus, Science Direct and Web of Science) upto January 2019. Plants like Acacia nilotica L., Achyranthes aspera Linn., Aegle marmelose L., Alillum sativum L., Aloe barbadensis Miller, Annona muricata L., Bacopa monnieri Linn., Carica papaya Linn., Centella asiatica Linn., Curcuma longa Linn., Elatoria cardamom L., Hibiscus rosa-sinensis L., Mangifera indica L., Mimosa pudica L., Moringa oleifera L., Ocimum sanctum Linn., Piper nigrum L., Phyllanthus embilica L., Terminalia chebula Retz., and Zingibera officinalis Roscoe. are available in Kerala, reported with antiulcer property. The secondary metabolites present in the plants like alkaloids, flavanoids, terpenoids, tannins, glycosides, terpines, and resins also have an important role in reliving ulcers due to its antisecretory, antioxidant, and cytoprotective properties. This review summarizes the botany, ethnopharmacology, phytochemistry and mechanism of action of antiulcer plants.
\end{abstract}

Key Words: Alkaloids, antiulcer, flavanoids; terpenoids.

Received: 28 May 2019, Accepted: 29 June 2019

Corresponding Author: Jincy Jacob, Department of Pharmacology, St. Joseph's College of Pharmacy, Cherthala, Kerala, India-688 524, Tel.:: +91 8078467305, E-mail: jincyjacobtj.7@gmail.com

ISSN: 1110-0930, 2020 Vol.58, No. $1 \& 2$

\section{INTRODUCTION}

Peptic ulcer is a group of ulcerative disorders that occur in the areas of the upper gastrointestinal tract that are exposed to acid-pepsin secretions. The most common causes of peptic ulcer are H. pylori infection and NSAID use. It can affect one or all layers of the stomach or duodenum. The two most common types of peptic ulcer are gastric ulcer and duodenal ulcer ${ }^{[1]}$. Duodenal ulcer is 2-4 times more prevalent than gastric ulcer type ${ }^{[2]}$. Gastric ulcers occur in the stomach, characterized by pain and are common in older age group. Nausea, vomiting and weight loss are the other symptoms of gastric ulcers. Although patients with gastric ulcers have normal or diminished acid production, yet ulcers may occur even in complete absence of acid $^{[3]}$. Duodenal ulcers are found at the beginning of small intestine and are characterized by severe pain with burning sensation in upper abdomen that awakens patients from sleep. Generally, pain occurs when the stomach is empty and relieves after eating. Duodenal ulcer is more common in younger individuals and predominantly affects males $^{[4]}$.

\section{Prevalence of peptic ulcer}

Peptic ulcer is one of the world's major gastrointestinal disorders and affecting $10 \%$ of the world population ${ }^{[5]}$. About 19 out of 20 peptic ulcers are duodenal. It is estimated that 15000 deaths occur each year as a consequence of peptic ulcer. The annual incidence estimates of peptic ulcer hemorrhage and perforation were $19.4-57$ and 3.8-14 per 100,000 individuals, respectively. The average 7-day recurrence of hemorrhage was $13.9 \%$ and the average longterm recurrence of perforation was $12.2 \%{ }^{[6]}$. According to the latest WHO data published in 2017 peptic ulcer disease deaths in India reached 57,658 or $0.66 \%$ of total deaths. The age adjusted death rate is 5.79 per 100,000 of population ranks India 53 in the world ${ }^{[7]}$. In the Indian pharmaceutical industry, antacids and antiulcer drugs share 6.2 billion rupees and occupy $4.3 \%$ of the market share ${ }^{[8]}$.

Peptic ulcer occurs in the gastrointestinal tract which is exposed to gastric acid and pepsin i.e. the stomach and duodenum. The etiology of peptic ulcer is not clearly known. It results probably due to the imbalance between aggressive and protective factors in the stomach ${ }^{[9]}$. Aggressive factors 
include Helicobacter pylori, hydrochloric acid $(\mathrm{HCl})$, pepsins, nonsteroidal anti-inflammatory drugs (NSAIDs), bile acids, ischemia, hypoxia, smoking and alcohol, while defensive factors include bicarbonate, mucus layer, mucosal blood flows, prostaglandins (PGs) and growth factors $^{[10]}$

In this context, the use of medicinal plants has gained interest of many researchers. Natural products are in continuous expansion all over the world and became the most attractive source of new drug and relatively less expensive, safe to use even at higher doses for the treatment and prevention of many diseases ${ }^{[1]}$. According to World Health Organization, medicinal plants would be the best source to obtain a variety of drugs. Therefore, such plants should be investigated to better understand their properties, safety and efficacy ${ }^{[12]}$. In order to achieve this aim, various sources like ancient traditional books, journals, libraries and internet were explored for each of the medicinal plants for peptic ulcers and all retrieved articles were evaluated to achieve clinical evidence for their efficacy and possible mechanisms. There by this review aims to summarize the antiulcer activity of medicinal plants found in Kerala.

\section{Antiulcer plants (Table 1)}

\subsection{Acacia nilotica (L.)}

A. nilotca belongs to the family of Mimosaceae. It is commonly known as "babul tree" and locally called as karuvelam. A. nilotica is commonly found all over India in dry and sandy localities, this species occurs only in Travancore district in low altitude dry forests where it attains larger dimensions ${ }^{[13]}$. The bark, leaves pods and flowers have traditionally been proved for various ailments like cancer, cold, congestion, cough, diarrhea, dysentery, fever, hypertension, hemorrhoid, ophthalmic, sclerosis, small pox, tuberculosis, leprosy, bleeding piles, leucoderma and menstrual problems ${ }^{[14]}$. Pharmacologically reported activities include anti-inflammatory ${ }^{[15]}$, antioxidant ${ }^{[16]}$, antidiarrhoeal $^{[17]}$, antihypertensive and antispasmodic ${ }^{[18]}$, antibacterial $^{[19]}$, anthelmintic ${ }^{[20]}$, antifungal ${ }^{[21]}$, antiplatelet aggregatory $^{[22]}$, analgesic $\left.{ }^{[15}\right]$, antipyretic ${ }^{[23]}$, antiviral ${ }^{[24]}$, anticancer $^{[25]}$ antidiabetic $^{[26]}$ and acetyl cholinesterase (AChE) inhibitory ${ }^{[27]}$. Phytochemically tannins 25\%$60 \%$, mucilage $20 \%-30 \%$, flavonoids, resins, saponins \& alkaloids have been isolated from different parts of A. nilotica ${ }^{[28]}$. The gastroprotective effect of $A$. nilotica young seedless pod extract was evaluated for antiulcer activity. Different extracts like ethanolic, 50\% hydroethanolic (50:50), 70\% hydroethanolic (70:30) and aqueous of young seedless pods were examined in pylorus ligation, swimming stress and NSAID induced gastric ulcers in wistar rats.

The hydroethanolic extracts $70 \%$ and $50 \%$ at the dose of 100 and $200 \mathrm{mg} / \mathrm{kg}$ significantly $(P \leq 0.05)$ reduced gastric volume, free acidity, total acidity, ulcer index and increased the mucin content. Further the $70 \%$ hydroethanolic extract also showed better protection as compared to $50 \%$ hydroethanolic extract, which was comparable to cimetidine treatment. Whereas, ethanolic and aqueous extracts were not found to be effective in reducing pylorus ligation-induced gastric ulceration. In swimming stress and NSAID induced ulcer models the $70 \%$ hydroethanolic extract at 100 and 200 $\mathrm{mg} / \mathrm{kg}$ significantly $(P \leq 0.05)$ decreased the ulcer index and increased the mucin content. Similar protection was also observed after treatment with diazepam ${ }^{[28]}$. From the study they concluded that the hydroethanolic extract of young seedless pods of $A$. nilotica has antiulcer activity in pylorus ligation, swimming stress and indomethacin induced ulcer rat models. Moreover the $70 \%$ hydroethanolic extract contains more amounts of phenolic components and it shown high antiulcer activity, which indicates that the phenolic component of the extract was found to be responsible for the activity of the extracts ${ }^{[28]}$.

Table 1:- Antiulcer plants in Kerala

\begin{tabular}{|c|c|c|c|c|c|c|}
\hline $\begin{array}{l}\text { S } 1 . \\
\text { No }\end{array}$ & Plant & $\begin{array}{l}\text { Plant part } \\
\text { used }\end{array}$ & Extract & Dose $(\mathrm{mg} / \mathrm{kg})$ & Standard & Mechanism of action \\
\hline 1 & Acacia nilotica & $\begin{array}{l}\text { Seedless } \\
\text { pod }\end{array}$ & $\begin{array}{l}\text { Ethanolic and } \\
\text { hydroethanolic } \\
\text { extract }\end{array}$ & 100 and 200 & $\begin{array}{l}\text { Cimetidine } \\
10 \mathrm{mg} / \mathrm{kg}\end{array}$ & $\begin{array}{l}\text { Antisecretory, mucosal defense mechanism, reduce } \\
\text { gastric motility, antioxidant }{ }^{[28]}\end{array}$ \\
\hline 2 & $\begin{array}{l}\text { Achyranthes } \\
\text { aspera }\end{array}$ & Leaf & $\begin{array}{l}\text { Ethanolic } \\
\text { extract }\end{array}$ & $\begin{array}{l}200,400, \text { and } \\
600\end{array}$ & $\begin{array}{l}\text { Omeprazole } \\
10 \mathrm{mg} / \mathrm{kg}\end{array}$ & Antisecretory and antioxidant ${ }^{[29]}$ \\
\hline 3 & $\begin{array}{l}\text { Aegle } \\
\text { marmelos }\end{array}$ & Leaf & $\begin{array}{l}\text { Ethanolic } \\
\text { extract }\end{array}$ & 200 and 400 & $\begin{array}{l}\text { Omeprazole } \\
20 \mathrm{mg} / \mathrm{kg}\end{array}$ & Cytoprotective ${ }^{[42]}$ \\
\hline 4 & Allium sativum & Garlic bulb & $\begin{array}{l}\text { Aqueous } \\
\text { extract }\end{array}$ & $\begin{array}{l}200,300 \text { and } \\
400\end{array}$ & $\begin{array}{l}\text { Ranitidine } \\
50 \mathrm{mg} / \mathrm{kg}\end{array}$ & $\begin{array}{l}\text { Antioxidant, anti-inflammatory, immune cell } \\
\text { modulatory and calcium modulatory actions }{ }^{[53]}\end{array}$ \\
\hline 5 & $\begin{array}{l}\text { Aloe } \\
\text { barbadensis }\end{array}$ & $\begin{array}{l}\text { Aloe vera } \\
\text { powder }\end{array}$ & Powder water & 200 & $\begin{array}{l}\text { Omeprazole } \\
20 \mathrm{mg} / \mathrm{kg}\end{array}$ & $\begin{array}{l}\text { Cytoprotective, }{ }^{[60]} \text { anti-inflammatory, }{ }^{[211]} \\
\text { gastric mucus production, }{ }^{[60]} \\
\text { antioxidant, }{ }^{[60]} \text { anti secretary, }{ }^{[60]}\end{array}$ \\
\hline 6 & $\begin{array}{l}\text { Annona } \\
\text { muricata }\end{array}$ & Leaf & $\begin{array}{l}\text { Hydroalcoholic } \\
\text { extract }\end{array}$ & $\begin{array}{l}50,100,200 \\
\text { and } 400\end{array}$ & $\begin{array}{l}\text { Omeprazole } \\
30 \mathrm{mg} / \mathrm{kg}\end{array}$ & $\begin{array}{l}\text { By mediating the synthesis of prostaglandins, }{ }^{[73]} \\
\text { decreases the gastric secretion and motility and } \\
\text { increases blood flow }{ }^{[212]}\end{array}$ \\
\hline
\end{tabular}




\begin{tabular}{|c|c|c|c|c|c|c|}
\hline 7 & $\begin{array}{l}\text { Bacopa } \\
\text { monnieri }\end{array}$ & $\begin{array}{l}\text { Whole } \\
\text { plant }\end{array}$ & $\begin{array}{l}\text { aqueous, } \\
\text { ethanolic } \\
\text { and carbon } \\
\text { tetrachloride } \\
\text { extracts }\end{array}$ & 200 and 400 & $\begin{array}{l}\text { Omeprazole } \\
20 \mathrm{mg} / \mathrm{kg}\end{array}$ & $\begin{array}{l}\text { Cytoprotective, Antioxidant, spasmolytic, increase } \\
\text { gastric mucosal production, increases prostaglandin } \\
\text { production }^{[82]}\end{array}$ \\
\hline 8 & Carica papaya & $\begin{array}{l}\text { Unripe } \\
\text { fruit, seed }\end{array}$ & $\begin{array}{l}\text { Hydro alcoholic } \\
\text { extract }\end{array}$ & 250 and 500 & $\begin{array}{l}\text { Rabeprazole } \\
20 \mathrm{mg} / \mathrm{kg}\end{array}$ & Antisecretory, ${ }^{[98]}$ Cytoprotective, ${ }^{[96]}$ \\
\hline 9 & $\begin{array}{l}\text { Centella } \\
\text { asiatica }\end{array}$ & Leaf & $\begin{array}{l}\text { Ethanolic } \\
\text { extract }\end{array}$ & $\begin{array}{l}100,200 \text { and } \\
400\end{array}$ & $\begin{array}{l}\text { Omeprazole } \\
20 \mathrm{mg} / \mathrm{kg}\end{array}$ & $\begin{array}{l}\text { Antioxidant, anti-inflammatory, reduction in gastric } \\
\text { motility, }{ }^{[106]}\end{array}$ \\
\hline 10 & $\begin{array}{l}\text { Curcuma } \\
\text { longa } \\
\text { (curcumin) }\end{array}$ & Compound & Curcumin & $\begin{array}{l}5,10,20,40 \\
80 \text { and } 100\end{array}$ & $\begin{array}{l}\text { Omeprazole } \\
20 \mathrm{mg} / \mathrm{kg}\end{array}$ & $\begin{array}{l}\text { Antisecretory, cytoprotective, antioxidant, } \\
\text { and anti-inflammatory }{ }^{[116]}\end{array}$ \\
\hline 11 & $\begin{array}{l}\text { Elettaria } \\
\text { cardamomum }\end{array}$ & $\begin{array}{l}\text { Dried } \\
\text { fruits }\end{array}$ & $\begin{array}{l}\text { Methanolic } \\
\text { extract }\end{array}$ & $\begin{array}{l}100,300 \text { and } \\
500\end{array}$ & $\begin{array}{l}\text { Ranitidine } \\
50 \mathrm{mg} / \mathrm{kg}\end{array}$ & $\begin{array}{l}\text { Decrease in gastric motility and inhibition of } \\
\text { production of some products of 5-lipoxygenase } \\
\text { pathway }{ }^{[18]}\end{array}$ \\
\hline 12 & $\begin{array}{l}\text { Hibiscus } \\
\text { rosa-sinensis }\end{array}$ & Leaf & $\begin{array}{l}\text { Methanolic } \\
\text { extract }\end{array}$ & 200 and 400 & $\begin{array}{l}\text { Omeprazole } \\
50 \mathrm{mg} / \mathrm{kg}\end{array}$ & Antisecretory activity ${ }^{[124]}$ \\
\hline 13 & $\begin{array}{l}\text { Mangifera } \\
\text { indica }\end{array}$ & $\begin{array}{l}\text { Seed } \\
\text { kernel }\end{array}$ & $\begin{array}{l}\text { Ethanolic } \\
\text { extract }\end{array}$ & $\begin{array}{l}100,200 \\
\text { and } 400\end{array}$ & $\begin{array}{l}\text { Ranitidine } \\
32 \mathrm{mg} / \mathrm{kg}\end{array}$ & $\begin{array}{l}\text { Antisecretory activity }{ }^{[140]} \text { Cytoprotective action by } \\
\text { increasing the mucus secretion } \\
\text { properties in an experimental rat model by reducing } \\
\text { gastric juice volume and acidity. }{ }^{[215]}\end{array}$ \\
\hline 14 & $\begin{array}{l}\text { Mimosa } \\
\text { pudica }\end{array}$ & Leaf & $\begin{array}{l}\text { Ethanolic } \\
\text { extract }\end{array}$ & 100 & $\begin{array}{l}\text { Ranitidine } \\
20 \mathrm{mg} / \mathrm{kg}\end{array}$ & $\begin{array}{l}\text { Cytoprotective, Antisecretory, Antiulcer activity } \\
\text { is due to the flavonoids and quercetin. Quercetin } \\
\text { may increase the amount of natural glycoproteins, } \\
\text { the most important proteins in the gastric mucosa, } \\
\text { which may in turn facilitate the defense against } \\
\text { an aggressive action. Quercetin also stimulates } \\
\text { the synthesis of cyclooxygenase and of local } \\
\text { prostaglandins. }{ }^{[142]}\end{array}$ \\
\hline 15 & $\begin{array}{l}\text { Muringa } \\
\text { oleifera }\end{array}$ & Root, bark & $\begin{array}{l}\text { Ethanolic } \\
\text { extract }\end{array}$ & $\begin{array}{l}150,350 \text { and } \\
500\end{array}$ & $\begin{array}{l}\text { Omeprazole } \\
30 \mathrm{mg} / \mathrm{kg}\end{array}$ & $\begin{array}{l}\text { Cytoprotective, Antisecretory, Increased mucus } \\
\text { secretion }^{[150]}\end{array}$ \\
\hline 16 & $\begin{array}{l}\text { Ocimum } \\
\text { sanctum }\end{array}$ & Leaf & $\begin{array}{l}\text { Aqueous and } \\
\text { ethanolic } \\
\text { extract }\end{array}$ & $\begin{array}{l}100,200 \text { and } \\
400\end{array}$ & $\begin{array}{l}\text { Ranitidine } \\
20 \mathrm{mg} / \mathrm{kg}\end{array}$ & Antisecretory, Cytoprotective ${ }^{[165]}$ \\
\hline 17 & Piper nigrum & Fruit & $\begin{array}{l}\text { Aqueous } \\
\text { extract }\end{array}$ & 500 & & $\begin{array}{l}\text { Inhibition of gastric motor activity, Stimulation } \\
\text { of prostaglandin synthesis, Mucosal defense } \\
\text { mechanism }^{[179]}\end{array}$ \\
\hline 18 & $\begin{array}{l}\text { Embilica } \\
\text { officinalis }\end{array}$ & $\begin{array}{l}\text { Dried } \\
\text { Fruit }\end{array}$ & $\begin{array}{l}\text { Hot and cold } \\
\text { water extract }\end{array}$ & 270 & $\begin{array}{l}\text { Ranitidine } \\
27 \mathrm{mg} / \mathrm{kg}\end{array}$ & $\begin{array}{l}\text { It deceased the gastric motility there by decreased } \\
\text { the gastric erosions, }{ }^{[191]} \text {. Decrease in the acid and } \\
\text { pepsin secretion (antisecretory activity). Increase } \\
\text { in the secretion of mucosal protective factors. } \\
\text { Mucus secreted from the mucus neck cells covers } \\
\text { the gastric mucosa thereby preventing physical } \\
\text { damage and back diffusion of hydrogen ions }{ }^{[213]} \text {. } \\
\text { It acts as antioxidant by decreasing the gastric } \\
\text { gastric peroxidase activity and it could be due to the } \\
\text { presence of Emblicanin A and B in its } \\
{ }^{[213]} \text { cytoprotective action }\end{array}$ \\
\hline 19 & $\begin{array}{l}\text { Terminalia } \\
\text { chebula }\end{array}$ & Fruit & $\begin{array}{l}\text { Methanolic } \\
\text { extract }\end{array}$ & 250 and 500 & $\begin{array}{l}\text { Omeprazole } \\
20 \mathrm{mg} / \mathrm{kg}\end{array}$ & Antisecretory, Cytoprotective ${ }^{[192]}$ \\
\hline 20 & $\begin{array}{l}\text { Zingiber } \\
\text { officinale }\end{array}$ & Root & $\begin{array}{l}\text { Aqueous } \\
\text { extract }\end{array}$ & 200 and 400 & $\begin{array}{l}\text { Omeprazole } \\
10 \mathrm{mg} / \mathrm{kg}\end{array}$ & $\begin{array}{l}\text { 5-lipoxygenase } \quad \text { inhibitory effect, }{ }^{[210]} \\
\text { Antisecretory }^{[216]}, \text { Increased mucin secretion }\end{array}$ \\
\hline
\end{tabular}

\subsection{Achyranthes aspera $L$.}

A. aspera (Amaranthaceae) is commonly known as kadaladi, vankadaladi, valiyakadaladi. The plant is found in Kottayam, Kazargod, Trivandrum, Malapuram and Alapuzha district in dry deciduous forests and forest plantations, also in the plains ${ }^{[13]}$. Traditionally the plant has been used to treat fever especially for malarial fever, dysentery, asthma, hypertension, and diabetes ${ }^{[29]}$. Pharmacologically reported activities include diuretic, anti-inflammatory, antifungal, abortifaciant, larvicidel, hypoglycemic, antifertility and anticancer ${ }^{[30]}$. The major phytochemical constituents like carbohydrates, sugars, alkaloids, saponins, flavonoids, tannins are present in 
A. aspera $^{[29]}$. The gastroprotective effect of $A$. aspera leaves were evaluated on pyloric ligation and ethanol induced ulcer model by Vijay et al. ${ }^{[29]}$. A. aspera leaves 200,400 and $600 \mathrm{mg} / \mathrm{kg}$ ethanolic extract significantly reduced the ulcer index $P \leq 0.05$ by $200 \mathrm{mg} / \mathrm{kg}, P \leq 0.01$ by $400 \mathrm{mg} / \mathrm{kg}$, and $P \leq 0.001$ by $600 \mathrm{mg} / \mathrm{kg}$ when compared to the ulcer control. In addition to this it also reduced the total acidity, free acidity, $\mathrm{pH}$ and gastric volume. The extent of gastro protection showed by the A. aspera extract $600 \mathrm{mg} /$ $\mathrm{kg}$ was $59.55 \%$ and $35.58 \%$ respectively against pyloric ligation and ethanol induced ulceration when compared to the standard drug omeprazole $83.14 \%$ and $50.25 \%$ respectively. A. aspera exerts cytoprotective effect in addition to its gastric antisecretory activity that could be due to the presence of flavonoids and tannins responsible for its protective effect by maintaining an efficient gastric mucosal microvascular supply ${ }^{[29]}$.

\subsection{Aegle marmelose L.}

A. marmelose (Rutaceae), commonly known as koolakam, koovalam, vilvam, mavilavu. The plant chiefly grows throughout Kerala in dry, open forests on hills and plains at altitudes from sea level to around $1200 \mathrm{~m}^{[13]}$. Traditionally, the unripe fruits are used as astringent, aid in digestion and stomach irritation. The half-ripe fruits are astringent, digestive and antidiarrheal. The ripe fruits are supposed to be more useful than the raw fruits and are used to prevent subacute and chronic dysentery ${ }^{[31]}$. Their leaves are traditionally used for the treatment of fever, abdominal pain, urinary troubles, heart palpitation, dysentery, dyspepsia, stomach pain, seminal weakness, vomiting and swellings ${ }^{[32]}$. Antioxidant ${ }^{[33]}$, hepatoprotective ${ }^{[34]}$, antidiabetic ${ }^{[35]}$, cardio protective $\mathrm{e}^{[36]}$, antipyretic, anti-inflammatory, and analgesic ${ }^{[37]}$, antimicrobial ${ }^{[38]}$, antifungal ${ }^{[39]}$, antidyslipidemic ${ }^{[40]}$, anticancer ${ }^{[41]}$, and antiulcer $^{[42]}$, are the pharmacologically reported activities. The antiulcer activity of 200 and $400 \mathrm{mg} / \mathrm{kg}$ ethanolic extract of A. marmelose leaves on rats were evaluated by Sharmin et al. ${ }^{[42]}$.

The ethanolic extract of $A$. marmelose leaves at $400 \mathrm{mg} /$ $\mathrm{kg}$ body weight showed significant reduction in ulcer spots in the stomach when compared to the control. Moreover, administration of ethanolic extract of $A$. marmelose and standard drug omeprazole both produced highly significant $(P \leq 0.001)$ antiulcer effect compared to control group. Percentage protection of ulcer with $400 \mathrm{mg} / \mathrm{kg}$ body weight of ethanolic extract of $A$. marmelose was found to be $56.33 \%$ when compared to the standard antiulcer drug omeprazole $(50.44 \%)^{[42]}$.

\subsection{Alillum sativum $L$.}

A. sativum (Liliaceae) is commonly known as garlic and locally known as veluthulli. This plant is a bulbous herb found in Idukki and Palakkad districts of
Kerala $^{[13]}$. Traditionally, it has been used in reducing cholesterol, blood pressure, free radicle scavenger, anti-platelet activity, thromboxane inhibiting activity and cardioprotective $^{[43]}$. Pharmacologically reported activities are antimicrobial, antioxidant ${ }^{[44]}$, antihypertensive ${ }^{[45]}$, cardioprotective $^{[46]}$, anti- atherosclerotic ${ }^{[47]}$, antidiabetic ${ }^{[48]}$, cancer chemopreventive $\mathrm{e}^{[49]}$, neuroprotective ${ }^{[50]}$, nephroprotective ${ }^{[51]}$ and immunomodulatory ${ }^{[52]}$. Potentially active phytochemical constituents in this plant are alliin, allicin, allinase, ajoene, peroxidase, arginine, selenium, germanium and tellurium ${ }^{[43]}$. The antiulcer activity of aqueous extract of $A$. sativum in pyloric ligation induced peptic ulcer in rats was evaluated by Arunachala et $a l .{ }^{[53]}$. The rats were treated with 200,300 , and 400 $\mathrm{mg} / \mathrm{kg}$ of aqueous extract of A. sativum for 10 days and it reduced the gastric volume, total acidity and free acidity, ulcerative index, total calcium, thiobarbituric acid reactive substances, myeloperoxidase levels and increase in total protein and reduced glutathione level in a dose dependent manner. The $400 \mathrm{mg} / \mathrm{kg}$ of aqueous extract of $A$. sativum showed significant $(P \leq 0.05)$ ulcer protective effect when compared to the standard ranitidine treated group. It has been concluded that the ulcer protective effect of aqueous extract of A. sativum may be due to its antioxidant, anti-inflammatory, immunosuppressive and anti-secretary action. Therefore, the aqueous extract of $A$. sativum may be a potent herbal candidate for the treatment of peptic ulcers $^{[53]}$.

\subsection{Aloe barbadensis Miller}

A. barbadensis is a perennial drought resisting herb belongs to the family Liliaceae. It is commonly known as aloe vera and locally known as kattarvazha, kattalai, Kattuvala, ghritakumari. This plant is found throughout Kerala $^{[13]}$. Traditionally the plant is used to treat burns, allergic reactions, acid indigesions, ulcers, diabetes skin diseases, uterine tonic, blood purifier, dysentery, diarrhea, piles and inflammatory conditions. Pharmacologically reported activities are anti-aging ${ }^{[54]}$, antioxidant and immunomodulatory ${ }^{[55]}$ antibacterial, antifungal ${ }^{[56]}$, antiviral $^{[57]}$, anti-mutagenic ${ }^{[58]}$, anti- diabetic ${ }^{[59]}$, and anti - ulcer ${ }^{[60]}$. The antiulcer effect of aloe vera was evaluated in non-steroidal anti-inflammatory drug induced peptic ulcers in albino rats by Sai et al. ${ }^{[60]}$. A. barbadensis $200 \mathrm{mg} / \mathrm{kg}$ showed antiulcer effect with mean ulcer index of $20 \pm 1.79$ compared to the standard omeprazole treated group with mean ulcer index of $10 \pm 1.96$. A. barbadensis possessed cytoprotective effects and acid reducing effects like omeprazole ${ }^{[60]}$.

\subsection{Annona muricata $L$.}

A. muricata (Annonaceae) is commonly known as guanabana, graviola, prickly custard apple and locally known as cancer chakka, mullanjakka, mulluathi, mullathi. A. muricata trees are found throughout Kerala ${ }^{[13]}$. 
Traditionally, A. muricata it has been used for fever, pain, respiratory and skin illness, internal and external parasites, bacterial infections, hypertension, inflammation, diabetes and cancer ${ }^{[61]}$. The pharmacologically reported activities are antimicrobial $^{[62]}$, anti-inflammatory ${ }^{[63]}$, anti-protozoan ${ }^{[64]}$, antioxidant ${ }^{[65]}$, anxiolytic and anti-stress ${ }^{[66]}$, antitumoral ${ }^{[67]}$, antiulcer $^{[68]}$, wound healing ${ }^{[69]}$, hepato-protective $\mathrm{e}^{[70]}$, hypoglycemic ${ }^{[71]}$, and hypotensive activities ${ }^{[72]}$. The antiulcerogenic activity of the hydroalcoholic extract of leaves of $A$. muricata was evaluated in mice by Elizangela et al. ${ }^{[73]}$. The mice were treated with 50, 100, 200 and 400 $\mathrm{mg} / \mathrm{kg}$ of hydroalcoholic extract of A. muricata. Gastric lesions were induced in mice by absolute ethanol, acidified ethanol and indomethacin. In ethanol induced ulcer model hydroalcoholic extract of $A$. muricata pretreatment at doses of $50,100,200$ and $400 \mathrm{mg} / \mathrm{kg}$ before the administration of absolute ethanol produced a significant reduction in lesion area by $92.89 \%, 94.13 \%, 97.79 \%$ and $96.55 \%$, respectively. From this detail it has been found that the hydroalcoholic extract of A. murcata at a dose of 200 and $400 \mathrm{mg} / \mathrm{kg}$ was more effective than the standard drug omeprazole (30 mg/kg p.o.), which showed a significant reduction in gastric lesion areas of $95.79 \%$. Whereas in indomethacin induced ulcer model hydroalcoholic extract of $A$. muricata at $200 \mathrm{mg} / \mathrm{kg}$ proved to be the most effective dose, by reducing the incidence of ulcers by $94.13 \%$. Hydroalcoholic extract of A. muricata at $400 \mathrm{mg} / \mathrm{kg}$ also decreased the incidence of ulcers significantly by $91.67 \%$. Omeprazole $(30 \mathrm{mg} / \mathrm{kg})$ reduced lesion rates by $96.82 \%$ compared with the ulcer control group. In acute gastric lesions induced study, the mice by acidified ethanol pretreatment with hydroalcoholic extract of A. muricata at doses of 50, 100, 200 and 400 $\mathrm{mg} / \mathrm{kg}$, showed a reduction in lesions of $47.69 \%, 76.23 \%$, $80.20 \%$ and $93.22 \%$, respectively. At a dose of $400 \mathrm{mg} / \mathrm{kg}$, hydroalcoholic extract $A$. muricata was as effective as the standard drug (omeprazole), which reduced the ulcer area by $93.22 \%$. The study confirmed that the gastroprotective action of $A$. muricata leaves and that this activity is modulated or mediated by the synthesis of prostaglandins, thereby determining the phytotherapeutic potential of this species to treat stomach ulcers and gastritis ${ }^{[73]}$.

\subsection{Bacopa monnieri L.}

B. monnieri (Scrophulariaceae) is commonly known as bacopa, thyme leaved gratiola and locally known as brahmi, neerbrahmi. This plant is found throughout Kerala $^{[13]}$. Traditionally it has been used to improve memory and intellect, anxiety, poor cognition and lack of concentration, as a diuretic and as an energizer for the nervous system and the heart. Specific uses include treatment of asthma, insanity and epilepsy. The plant has been utilized extensively as a nootropic, digestive aid and to improve learning and respiratory function $^{[74]}$. Pharmacologically reported activities are sedative and tranquillizer ${ }^{[75]}$, cogntion ${ }^{[76]}$, antioxidant ${ }^{[77]}$, $\operatorname{antidepressant}^{[78]}$, antianxiety ${ }^{[79]}$ adaptogenic ${ }^{[80]}$ and gastrointestinal disorders ${ }^{[81]}$. The antiulcerogenic activity of $B$. Monnieri on ethanol-induced gastric ulcer model was evaluated by comparing the efficacy of 200 and $400 \mathrm{mg} / \mathrm{kg}$ of aqueous, ethanolic and carbon tetrachloride extracts ${ }^{[82]}$. The histopathological results and microscopic damage scores of the treated animals with aqueous and carbon tetrachloride extracts of $B$. monnieri exhibited moderate to poor protection against gastric ulcers when compared with treatment with standard drug (Omeprazole). On the other hand, the ethanolic extract of B. monnieri (200 and $400 \mathrm{mg} / \mathrm{kg}$ b.w.) potentially regulated the inflammatory response that correspond to omeprazole ( $20 \mathrm{mg} / \mathrm{kg} \mathrm{b.w.)} \mathrm{as}$ evidenced by reduced ulcer index and microscopic score along with the results of histopathological evaluation. It has been reported that flavonoids and phenols are present in the three extracts. The presence of high flavonoid and phenolic contents may favor the ethanolic extract of $B$. monnieri to possess significant protective effect against ulcer when compared with other two extracts. Pretreatment with both doses (200 and $400 \mathrm{mg} / \mathrm{kg}$ ) of all three extracts (except carbon tetrachloride extract of B. monnieri of 200 $\mathrm{mg} / \mathrm{kg})$ showed significant result $(P \leq 0.01)$ for UI value when compared with ulcer control. Both aqueous and carbon tetrachloride extracts of B. monnieri showed significant difference $(P \leq 0.01)$ in UI values when compared with the reference drug (omeprazole, $20 \mathrm{mg}$ / $\mathrm{kg})$. The ethanolic extract of B. monnieri $(400 \mathrm{mg} / \mathrm{kg})$ showed significant protection against gastric ulcer same as omeprazole (20 mg/kg b.w. $)^{[82]}$.

\subsection{Carica papaya L.}

C. papaya belongs to the family Caricaceae. It is locally known as papaya, kappalanga, karmmoose, kappanga, ampapaya. This herbacious tree is found throughout Kerala $^{[13]}$. Traditionally it has been used as antihypertensive, wound healing, anti-inflammatory, anthelmintic and antiulcer $^{[83]}$. Pharmacologically reported activities are antioxidant $^{[84]}{ }^{2}$ antihypertensive ${ }^{[85]}$, anti-inflammatory ${ }^{[86]}$, antimicrobial $^{[87]}$, antifungal ${ }^{[88]}$, histaminergic ${ }^{[89]}$, diuretic ${ }^{[90]}$, anti-amoebic ${ }^{[91]}$, anti-tumour and immunomodulatory ${ }^{[92]}$, anthelminthic ${ }^{[93]}$, antimalarial ${ }^{[94]}$, hypoglycemic ${ }^{[95]}$, antiulcer $^{[96]}$ and anti-sickling ${ }^{[97]}$. Papain, chymopapain, pectin, carpain, carposide, carotinoids, vitamin C and antheraxanthin are pharmacologically important compound in this plant[83]. Ramandeep et al. evaluated the antiulcer activity of hydroalcoholic extract of unripe fruit of $C$. papaya in experimental rats. In this study they were used 250 and $500 \mathrm{mg} / \mathrm{kg}$ of hydroalcoholic extract of C. papaya in pylorus ligation and forced swimming induced ulcer models ${ }^{[98]}$. In both ulcer models, reduced ulcer index, gastric volume, free acidity and total acidity suggested that hydroalcoholic extract of $C$. papaya fruits have the antisecretory and antiulcerogenic activity. From the study it has been found that the hydroalcoholic extract of C. papaya $250 \mathrm{mg} / \mathrm{kg}$ showed decreased number of erosions in mucosa but still there is inflammation with 
areas of haemorrhage. Further there was a decreased extent of gastric mucosal rupture. Whereas $500 \mathrm{mg} / \mathrm{kg}$ effectively decreased the epithelial cell lose, gastric lesions and haemorrhage ${ }^{[98]}$.

\subsection{Centella asiatica $L$.}

C. asiatica (Apiaceae) is commonly known as gotu kola, Indian penny - wort, pohekula, sadeleaf and locally known as kodangal, kudakan, mutthil, vellara. C. asiatica is a prostate herb found throughout Kerala in wet places of the plain and deciduous forest ${ }^{[13]}$. Traditionally it has been used as a best herb for improving memory and intellect. It also used in CNS disorders like epilepsy, schizophrenia and cognitive dysfunction, renal stones, leprosy and skin diseases, anorexia and asthma. In other traditional systems, it has been additionally used in the management of diarrhoea, cholera, measles, jaundice, leukorrhoea, haematemesis, hepatitis, urethritis, toothache, syphilis, smallpox, neuralgia, rheumatism, toothache and as an antipyretic, analgesic and antiinflammatory. Poultices have been used to treat contusions, closed fractures, sprains and furunculosis ${ }^{[99]}$. Pharmacologically reported activities include management of fibroblast proliferation and collagen synthesis ${ }^{[100]}$, antioxidant activity ${ }^{[101]}$, antiulcer $^{[102]}$, anticancer ${ }^{[103]}$, anti-bacterial activity ${ }^{[104]}$ and anti-inflammatory activity ${ }^{[105]}$. The roots are rich in amino acids, especially aspartic, glutamic, serine, threonine, alanine, lysine and histidine ${ }^{[99]}$.

The antiulcer activity of $C$. asiatica leaves extract against ethanol induced gastric mucosal injury in rats was evaluated by Abdulla et al. ${ }^{[106]}$. Adult Sprague Dawley rats treated orally with carboxymethyl cellulose (CMC) solution (ulcer control group), Omeprazole $20 \mathrm{mg} / \mathrm{kg}$ (reference group), and 100, 200 and $400 \mathrm{mg} / \mathrm{kg} \mathrm{C}$. asiatica leaf extract in $\mathrm{CMC}$ solution (experimental groups) for the experiment. $C$. asiatica leaf extract showed a dose dependent reduction in the gastric ulcer, edema and leucocytes infiltration of mucosal layers when compared to the control. The protection was most prominent at a dose $400 \mathrm{mg} / \mathrm{kg}$ of leaves extract. From the study it has been found that the mechanism of antiulcer activity may be due to antioxidant, anti-inflammatory and also due to the reduction in the gastric motility ${ }^{[106]}$.

\subsection{Curcuma longa $L$.}

C. longa Linn. (Zingiberaceae) is commonly known as turmeric and locally known as manjal. This plant is a rhizomatous herb found throughout Kerala ${ }^{[13]}$. Traditionally it has been used for dressing wounds, treat bites, burns, acne, skin diseases, respiratory ailments, dental diseases, digestive disorders such as dyspepsia and acidity, indigestion, flatulence, ulcers, antioxidant, antifertility as well to alleviate the hallucinatory effects of hashish, and other psychotropic drugs ${ }^{[107]}$. Pharmacologically reported activities are anti-inflammatory ${ }^{[108]}$, antioxidant ${ }^{[109]}$, chemopreventive and chemotherapeutic activity ${ }^{[110]}$, antiulcer ${ }^{[107]}$ anticoagulant ${ }^{[111]}, \quad$ antidiabetic ${ }^{[112]}$, antimicrobial $^{[113]}$ antifunga ${ }^{[144]}$ and antiviral ${ }^{[115]}$ Phytochemical constituents in this plant are curcumin, demethoxycurcumin, bisdemethoxycurcumin, protein, fat, minerals, carbohydrates, phellandrene, sabinene, cineol, borneol, zingiberene, and sesquiterpenes ${ }^{[111]}$. Karolin conducted a comparative evaluation of the antiulcer activity of curcumin and omeprazole during acute phase of gastric ulcer. Results obtained showed that curcumin and omeprazole significantly decreased gastric lesion formation $(P<0.001)$ in the gastric wall from $33.15 \pm 3.899$ lesions/ animal in control group to $4.000 \pm 0.6602$ and to 8.215 \pm 0.8787 lesions/ animal in treated groups with curcumin and omeprazole, respectively. Therefore, the preventive index was re-corded $85.75 \pm 2.851$ and $71.71 \pm 2.697 \%$ for curcumin and omeprazole treated group, respectively. It also reduced the plasma peroxide, gastric acidity and IL-6 whereas; gastric mucin content and VGEF level are increased. Curcumin exerts its anti-ulcer activity not only by affecting oxidative stress and total antioxidant capacity but also by inhibiting IL-6 secretion and preventing apoptosis. Furthermore, curcumin promotes gastric ulcer pre-venation/healing by induction of angiogenesis in the granular tissue of ulcers ${ }^{[116]}$.

\subsection{Elatoria cardamom L.}

E. cardamom belongs to the family of Zingiberaceae. It is commonly known as cardamom and locally known as ealakkaya, eallam, elam, elattari. This plant is found in Palakkad, Idukki, Kollam, Pathanamthitta, Malappuram, Kannur, Thiruvananthapuram, Thrissur and Wayanad districts of Kerala ${ }^{[13]}$. Traditionally it has been used for aromatic, cardiac, carminative, deodorant, digestive, diuretic, expectorant, purgative, stimulant, thirst reliever and tonic. It is also useful in asthma, burning sensation, cold and cough, diseases of bladder and kidney, flatulence, heart weakness, indigestion, scanty urine and piles ${ }^{[177]}$. Pharmacologically reported activities are anti-inflammatory, analgesic, insecticidal, anthelmintic, laxative, antiulcer, diuretic. Terpineol, terpinene, cineol, limonene, sabinene are the phytochemical constituents in this plant ${ }^{[117]}$. The gastroprotective effect of cardamom was evaluated in the gastric lesions induced by asprin, ethanol and pylorous by Jamal et al. ${ }^{[18]}$. Rats were treated with methanolic extract of cardamom, petroleum ether soluble fractions, petroleum ether insoluble fractions, essential oil and $\mathrm{CMC}^{[18]}$.

First, they conducted experiment on ethanol induced ulcer model, in that experiment Wistar rats were treated with methanolic extract $(500,300$ and $100 \mathrm{mg} / \mathrm{kg})$, Petroleum ether soluble fraction $(50 \mathrm{mg} / \mathrm{kg})$, petroleum ether insoluble fraction $(450 \mathrm{mg} / \mathrm{kg})$ and essential oil $(50 \mathrm{mg} /$ $\mathrm{kg}$ ) in order to determine the fraction containing most 
active principle. The pretreatment with methanolic extract (500, 300 and $100 \mathrm{mg} / \mathrm{kg}$ ) showed a dose dependent reduction in the severity of the lesions. The petroleum ether soluble and petroleum ether insoluble fractions showed significant inhibition of ulceration by $50 \%$ and $54.8 \%$, respectively. Petroleum ether soluble fraction is found to be more active when compared to petroleum ether insoluble fractions and moreover petroleum ether soluble faction at a dose $100 \mathrm{mg} / \mathrm{kg}$ produced sub maximal response. The essential oil was found to be more active than petroleum ether soluble fractions $(73.3 \%$ and $50.0 \%$ inhibition, respectively). They found that the active principles in essential oil are responsible for gastro protective action. In addition to that, essential oil reduced $65 \%$ of the ulcer index ${ }^{[118]}$.

For their second experiment, aspirin induced ulcer models were used. In that animals were treated with methanolic extract $(500 \mathrm{mg} / \mathrm{kg})$ and its petroleum ether insoluble fraction $(450 \mathrm{mg} / \mathrm{kg})$ and petroleum ether soluble fractions $(50,37.5,25$ and $12.5 \mathrm{mg} / \mathrm{kg}$ ), essential oil $(12.5 \mathrm{mg} / \mathrm{kg})$ and ranitidine $(50 \mathrm{mg} / \mathrm{kg})$. All the fractions showed significant inhibition of ulceration. Petroleum ether soluble fraction was found to be more active than essential oil and ranitidine. Thus, they concluded that constituents other than essential oil present in petroleum ether soluble fractions are also involved in the gastroprotective action. However, it significantly inhibited the ulcer formation $(71.7 \%)$ in aspirin induced gastric ulceration in Shay rats. The ulcer index $(\mathrm{mm})$ in the control and PS-treated rats were $1.06 \pm 0.07$ and $0.30 \pm 0.04$, respectively ${ }^{[118]}$.

Finally, they were used pyloric ligation induced ulcer models treated with CMC $(10 \mathrm{ml} / \mathrm{kg})$, ranitidine $(50 \mathrm{mg} / \mathrm{kg})$, methanolic extract $(500 \mathrm{mg} / \mathrm{kg})$ and petroleum ether soluble fractions $(50 \mathrm{mg} / \mathrm{kg})$. In that experiment they found that pretreatment with ethanolic extract $(500 \mathrm{mg} / \mathrm{kg})$ and petroleum ether soluble fractions $(50 \mathrm{mg} / \mathrm{kg})$ did not have any significant effect on the gastric ulcers induced by pylorus ligation. On the basis of these findings, they came to a conclusion that, gastroprotective action of petroleum ether soluble fractions and essential oil are due to the inhibition of the overproduction of some products of the 5-lipoxygenase pathways and also due to the decrease in the gastric motility and further studies were needed to test this hypothesis ${ }^{[118]}$.

\subsection{Hibiscus rosa-sinensis}

H. rosa (Malvaceae) is commonly known as Shoe flower and locally known as ayamparathi, chembarathi. This plant is an annual or perennial herbaceous bush found throughout Kerala ${ }^{[13]}$. Traditionally the leaves and flowers are observed to be promoters of hair growth and aid in healing of ulcers. Flowers have been found to be effective in the treatment of arterial hypertension and to have significant antifertility effect ${ }^{[119]}$. Pharmacologically reported activities are anti-spermatogenic and androgenic ${ }^{[120]}$ antitumor $^{[121]}$, anticonvulsant ${ }^{[122]}$, anti-diabetic ${ }^{[123]}$, antiulcer ${ }^{[124]}$ and hair growth promoter ${ }^{[125]}$. Phytochemical constituents in this plant are anthocyanins and flavonoids, cyanidin3,5-diglucoside, cyanidin- 3-sophoroside-5-glucoside, quercetin-3,7-diglucoside, quercetin- 3-diglucoside, a cyclopeptide alkaloid, cyanidin chloride, quercetin, hentriacontane and vitamins: riboflavin, ascorbic acid and thiamine have been reported ${ }^{[119]}$.

The antiulcer activity of methanolic extract of $H$. rosa leaves was evaluated by Srivastava et al..$^{[124]}$ using pylorus ligation induced ulcer model. In their experiment animals were treated with Sodium CMC, $0.3 \%$, standard drug omeprazole $(80 \mathrm{mg} / \mathrm{kg})$, methanolic extract of H. rosa (200 and $400 \mathrm{mg} / \mathrm{kg}$ ) respectively and the extracts showed a reduction in the parameters like volume of acid, free acidity, total acidity and ulcer score. The methanolic extract $(400 \mathrm{mg} / \mathrm{kg})$ showed highly significant $(P \leq 0.001)$ reduction whereas the methanolic extract $(200 \mathrm{mg} / \mathrm{kg})$ showed significant $(P \leq 0.01)$ reduction in all the parameters when compared with control ${ }^{[124]}$.

\subsection{Mangifera indica $L$.}

M. indica (Anacardiaceae) commonly known as mango tree and locally known as amaram, manga, mampazham, mavu and moochi. This tree is found throughout Kerala in evergreen and semi-evergreen forests ${ }^{[13]}$. Traditionally it has been used to treat diabetes, gastric disorders, asthma, mouth sores, bleeding hemorrhoids, lung hemorrhage, anemia, nerve disorders and cough ${ }^{[126]}$. Pharmacologically reported activities include anticancer, ${ }^{[127]}$ anti-inflammatory ${ }^{[128]}$ antidiabetic ${ }^{[129]}$ antioxidant ${ }^{[130]}$, antibacterial ${ }^{[131]}$, antifungal ${ }^{[132]}$, anthelminthic ${ }^{[133]}$, gastro protective $^{[134]}$, hepatoprotective ${ }^{[135]}$, immunomodulatory ${ }^{[136]}$, Anthelmintic ${ }^{[137]}$, Antiviral ${ }^{[138]}$ and antihyperlipemic effects ${ }^{[139]}$. Pharmacologically important compounds like mangiferin, quercetin, catechin, ellagic acid, shikimic acid, friedeline, $\alpha$-amyrin, $\beta$ - amyrin, gallic acid, ferulic acid, cinnamic acid, and vanilline have been reported ${ }^{[126]}$. The antiulcer activity of ethanolic extract of $M$. indica seed kernel using acid ethanol induced ulcer model was evaluated using acid ethanol induced ulcer model by Prabhu et al. ${ }^{[140]}$. In the study female albino rats of Wistar strains were treated with ethanolic extract of $M$. indica $(100,200$ and $400 \mathrm{mg} / \mathrm{kg} \mathrm{b.w.)} \mathrm{for} 15$ days. M. indica seed kernel $(400 \mathrm{mg} / \mathrm{kg})$ significantly $(P \leq 0.05)$ reduced the ulcer index, $\mathrm{pH}$, total acidity, LPO and protein levels. Percentage ulcer protection was found to be $70 \%$ and it also acted as a good antioxidant ${ }^{[140]}$.

\subsection{Mimosa pudica L.}

M. pudica (Fabaceae) commonly known as sensitive plant, humble plant, touch me not and locally known as theendarmani, thottalvadi, thottavadi. This is a stout 
stragling prostrate shrubby plant found throughout Kerala as a weed ${ }^{[13]}$. Traditionally it has been used in diseases due to corrupted blood and bile, billious fever, piles, jaundice, leprosy, ulcers, small pox ${ }^{[141]}$. Pharmacologically reported activities are anti-hyperglycemic, antidiarrheal, anti-convulsant and cytotoxic ${ }^{[141]}$. The ethanolic leaf extract of $M$. pudica was evaluated in rats by using ethanol, aspirin and pylorus ligation induced ulcer models by Elango et al. ${ }^{[142]}$ M. pudica ethanolic extract $100 \mathrm{mg} / \mathrm{kg}$ body weight and ranitidine $20 \mathrm{mg} / \mathrm{kg}$ body weight for 5 days. It showed antiulcer activity in all the three models and significantly $(P \leq 0.01)$ reduced the ulcer incidence when compared to the control. It also showed a decrease in gastric volume, free acidity and total acidity in the animal groups treated with ethanolic extract. From the study it has been found that $M$. pudica the protection against ulcerations in aspirin and ethanol induced ulcer models indicate cytoprotective action by extracts of $M$. pudica and anti-secretory activity of the extracts was noticed in pylorus ligation induced ulcer model ${ }^{[142]}$.

Quercetin is pharmacologically important compound present in this plant, which has the power to prevent gastric mucosal lesions induced by various models (pylorus ligation, ethanol induced, cold restraint stress). It may also increase the amount of natural glycoproteins, the most important proteins in the gastric mucosa, which may in turn facilitate the defence against an aggressive action and stimulates the synthesis of cyclooxygenase and local prostaglandins. Other mechanisms proposed include inhibition of the gastric proton pump and lipoxygenase pathway, or inhibition of lipid peroxidation ${ }^{[142]}$.

\subsection{Moringa oleifera $L$.}

M. oleifera (Moringaceae) commonly known as drumstick tree and locally known as muringa, moringa and sigru. This tree is found throughout Kerala ${ }^{[13]}$. Traditionally it has been used for treating heart burn, diarrhea, malaria, diabetes, blood pressure, cholesterol, ulcer, inflammation, cold and urinary problems ${ }^{[143]}$. Pharmacologically reported activities are cardiac stimulant, anticancer $^{[144]}$, antiepileptic, antipyretic, wound healing ${ }^{[145]}$, analgesic $^{[146]}$ antispasmodic ${ }^{[147]}$ radioprotective ${ }^{[148]}$, antioxidant and hepatoprotective $\mathrm{e}^{[149]}$, antihypertensive, diuretic, anti-diabetic, cholesterol lowering, antibacterial, neuroprotective and antifungal ${ }^{[143]}$. Phytochemical constituents in this plant are fatty acid, protein, vitamin $\mathrm{C}$, calcium, terpenoids, flavonoids, lectins, amino acids, minerals, linoleic acid, oleic acid, palmitic acid and linoleic $\operatorname{acid}^{[143]}$.

Choudhary et al. assessed the antiulcer potential of M. oleifera root-bark extract in albino Wistar rats using ethanol-induced and pylorus ligation-induced gastric ulceration by treating with three different doses of the extract $(150,350$, and $500 \mathrm{mg} / \mathrm{kg})$ for 15 consecutive days. The
350 and $500 \mathrm{mg} / \mathrm{kg}$ of $M$. oleifera significantly $(P \leq 0.01)$ decreased the ulcer index as compared to the control group. The percentage protections against gastric ulcers were $82.58 \%, 85.13 \%$, and $86.15 \%$ at the doses of 150 , 350 , and $500 \mathrm{mg} / \mathrm{kg}$, respectively, in pylorus-ligated ulcer model and $55.75 \%, 59.33 \%$, and $78.51 \%$, respectively, in ethanol-induced ulcer model. It also reduced the free acidity, total acidity, and ulcer index and increased the $\mathrm{pH}$ of gastric content compared with the control group. ${ }^{[150]}$.

\subsection{Ocimum sanctum $L$.}

O. sanctum (Lamiaceae) commonly known as Basil, Sacred basil, holy basil and locally known as govindapushpam, krishnathulasi, thulasi, thrithavu, karuthathrithavu. This plant is a subshurb found throughout Kerala ${ }^{[13]}$. Traditionally it has been used for common colds, headaches, stomach disorders, inflammation, heart disease, various forms of poisoning and malaria ${ }^{[151]}$. Pharmacologically reported activities are antidiabetic, hypolipdemic and antioxidant ${ }^{[152]}$, cardioprotective activity ${ }^{[153]}$, wound healing ${ }^{[154]}$, radioprotective $^{[155]}$, gastroprotective ${ }^{[156]}$, anti-microbial ${ }^{[157]}$, immunomodulatory ${ }^{[158]}$, analgesic, antipyretic and anti-inflammatory ${ }^{[159]}$, sexually transmitted diseases ${ }^{[160]}$, anti-fertility ${ }^{[161]}$, anthelmintic ${ }^{[162]}$, anticancer ${ }^{[163]}$, thyroid activities $^{[164]}$. Phytochemical constituents in this plant are carvacrol, caryophyllene, eugenol, linalool, urosolic $\operatorname{acid}^{[151]}$.

In 2013 Bharat et al., evaluated the antiulcer activity of aqueous and ethanolic leaf extract of tulasi in albino rats. The dose 100,200 and $400 \mathrm{mg} / \mathrm{kg}$ of $O$. sanctum has been used for the study. The aqueous and ethanolic extract of $O$. sanctum $(200 \mathrm{mg} / \mathrm{kg}$ bw) showed significant $(P \leq 0.05)$ reduction in gastric volume, free acidity, total acidity, combined acidity and ulcer index as compared to the control group of pyloric ligations, cold restraint stress and forced swim endurance ulcer induced model and it also shown anti- secretary mechanism. This study showed that aqueous and ethanolic leaf extract of $O$. santum is effective as that of the standard synthetic drug Ranitidine ${ }^{[165]}$.

\subsection{Piper nigrum $L$.}

P. nigrum (Piperaceae) commonly known as black pepper and locally known as kurumulaku, mulakukodi, nallamulaku. It is a glabrous climber found throughout Kerala in evergreen, semi-evergreen forests and also cultivated $^{[13]}$. Traditionally it is used for carminative, stimulant and stomachic ${ }^{[166]}$. Pharmacologically reported activities are antihypertensive and antiplatelets ${ }^{[167]}$, antioxidant ${ }^{[168]}$, antitumor and immunomodulatory ${ }^{[169]}$, anti- asthmatics ${ }^{[170]}$, analgesic and anticonvulsant ${ }^{[171]}$, anti-inflammatory ${ }^{[172]}$, anti-diarrheal ${ }^{[173]}$, antispasmodic, anxiolytic, antidepressants ${ }^{[174]}$, hepato-protective ${ }^{[175]}$, antibacterial ${ }^{[176]}$, antifungal, anti-thyroids, antiapoptotic, 
anti-metastatic, antimutagenic, anti-spermatogenic, anticolon toxin ${ }^{[177]}$, insecticidal and larvicidal activities ${ }^{[178]}$. Phytochemical constituents in this plant are Phenolics, flavonoids, alkaloids, amides and steroids, lignans, neolignans, terpenes, chalcones, piperin ${ }^{[166]}$. AL-Saeed et al. studied the effect of aqueous extract of $P$. nigrum on some physiological and histopathological parameters in aspirin induced gastric ulcer model rabbits. In the study, he was reported that the aqueous extract of $P$. nigrum showed a significant $(P \leq 0.05)$ increase in $\mathrm{RBC}, \mathrm{WBC}, \mathrm{PCV}, \mathrm{Hb}$ and a significant decrease in the glucose, cholesterol and activities of AST and ALT when compared to the respective controls. Whereas aspirin and $P$. nigrum treated group showed significant reductions in RBC, WBC, $\mathrm{Hb}, \mathrm{PCV}$ and $\mathrm{MCHC}$ when compared to the respective controls. Moreover, treatment with aqueous extract of $P$. nigrum $(500 \mathrm{mg} / \mathrm{kg}$ ) for 30 days was found to be inhibiting the ulcers induced by aspirin. It prevented the increase of gastric acid secretions, depletion of stomach wall mucus and prevented the histological changes caused by aspirin. It has been found that it might be due to the stimulation of bioenergetics processes in the gastric epithelium under the influence of $P$. nigrum $^{[179]}$.

\subsection{Phyllanthus embilica L.}

P. embilica (Phyllanthaceae) commonly known as Indian gooseberry, emblic myrobalan and locally known as nellikka, nelli, amalakam. It is a deciduous tree found in dry and moist deciduous forests, throughout the tropics of Kerala ${ }^{[13]}$. Pharmacologically reported activities are antioxidant ${ }^{[180]}$, anticancer ${ }^{[181]}$, antigenotoxic ${ }^{[182]}$, anti- inflammatory ${ }^{[183]}$, antidiabetic ${ }^{[184]}$, antidepressant ${ }^{[185]}$, antiulcerogenic ${ }^{[186]}$, wound healing activities ${ }^{[187]}$, eye disorders ${ }^{[188]}$, cardiovascular diseases ${ }^{[189]}$ and neurodegenerative diseases ${ }^{[190]}$.

Joshi et al. evaluated the gastric motility of $P$. embilica and Asparagas racemosus in cold stress induced gastric damage. They were compared the effect of four different formulations of $P$. emblica, namely dry powder, hot water extract, cold water extract and incinerated powder and $A$. racemosus were administered orally in the dose of $270 \mathrm{mg} / \mathrm{kg}$ for 7 days. In case of no stress induced animals the $\%$ GE for drug treated groups was $64.16 \pm 17.29$, $58.33 \pm 5.95,50.00 \pm 7.56$ and $64.50 \pm 16.15$ in rats treated with dry powder, hot water extract, cold water extract and incinerated powder respectively. The percentage gastric emptying of rats administered Ranitidine was $58.00 \pm 19.51 \%$, gastric emptying shown by $A$. racemosus was $76.66 \pm 5.88$, which was significantly greater than the control group. None of the $P$. emblica groups showed significant gastric motility changes as compared to control group and ranitidine $(P \leq 0.05)$. Whereas in case of cold stress induced animal models treated with all the formulations of $P$. emblica and $A$. racemosus reversed the stress induced decrease in gastric emptying. All test groups showed improvement in percentage of gastric emptying time which was found to be statistically significant $(P \leq 0.01)$ as compared to control group, hot water extract showed highest improvement in gastric emptying. Thus they came to a conclusion that the mechanism of antiulcer activity of $P$. emblica and $A$. racemosus due to the gastric motility enhancing effect ${ }^{[191]}$.

\subsection{Terminalia chebula Retz.}

T. chebula (Combretaceae) commonly known as gallnut, black myrobalan, and chebulic myrobalan and locally known as kadukka, pulicakku, putanam. It is a deciduous tree found in dry and moist deciduous forests of Idukki, Thiruvananthapuram, Kozhikkode, Wayanad, and Palakad districts of Kerala ${ }^{[13]}$. Traditionally has been used for treating constipation, diarrhea, ulcers, gastroenteritis, asthma, cough, dyspnea, dyspepsia, hemorrhoids, candidiasis, parasites, malabsorption syndrome, hepatomegaly, vesicular and renal calculi, urinary discharges, tumors, skin diseases, leprosy, intermittent fever, rheumatism, arthritis, gout, neuropathy, paralysis, memory loss, epilepsy, depression, diabetes, cardiovascular diseases, anorexia and wounds ${ }^{[192]}$. Pharmacologically reported activities are antibacterial, antifungal, antiviral, anticarcinogenic, antioxidant, adaptogenic and antianaphylactic, hypolipidemic, hepatoprotective, cardio protective, antidiabetic, wound healing, antiulcer, immunomodulatory and chemo preventive ${ }^{[193]}$. The antiulcer activity of methanolic extract of $T$. chebula fruits was evaluated in wistar rats by using pylorus ligation and ethanol induced ulcer models by Raju et al. ${ }^{[192]}$ It has been found that in both models the extract $(250 \mathrm{mg} / \mathrm{kg}$ and $500 \mathrm{mg} / \mathrm{kg})$ shown a significant $(P \leq 0.01)$ reduction in gastric volume, free acidity and ulcer index as compared to control. In pyloric ligation induced ulcer model the protection index was found to be $76 \%$ and $82 \%$ at the dose of 250 and $500 \mathrm{mg} / \mathrm{kg}$ in comparison to control and the omeprazole reference standard drug shown $84 \%$ reduction of ulcer. Where as in ethanol induced ulcer model methanolic extract of $T$. chebula has shown significant protection index of $54 \%$ and $66 \%$ with the dose of 250 and $500 \mathrm{mg} / \mathrm{kg}$ respectively in comparison to control, omeprazole as reference standard drug was reduction of ulcer $72 \%$. Finally, they concluded that $T$. chebula fruit extract have potential antiulcer activity in the both models. These results may further suggest that methanolic extract was found to possess antiulcerogenic as well as ulcer healing properties, which might be due to its antisecretory activity ${ }^{[192]}$.

\subsection{Zingibera officinalis Roscoe.}

Z. officinalis (Zingiberaceae) commonly known as ginger and locally known as andrakam, chukku, erukizhangu, inchi. It is a rhizomatous herb found throughout Kerala ${ }^{[13]}$. Traditionally it is used for nausea, 
vomiting, asthma, cough, palpitaion, inflammation, dyspepsia, loss of appetite, constipation, indigestion and pain $^{[194]}$. Pharmacologically reported activities are antioxidant and antimicrobial ${ }^{[195]}$, anticancer ${ }^{[196]}$, antidiabetic ${ }^{[197]}$, anti-inflammatory ${ }^{[198]}$, analgesic ${ }^{[199]}$, antipyretic $^{[200], \quad \text { immunomodulatory }}{ }^{[201]}$, anti-platelet aggregation $^{[202]}$, antiangiogenic ${ }^{[203]}$, hepato- protective ${ }^{[204]}$, antiemetic $^{[205]}$, neuroprotective ${ }^{[206]}$ anthelmintic ${ }^{[207]}$, gastro protective $e^{[208]}$ and cardiovascular ${ }^{[209]}$. Terpenes, alcohols, ketones, flavanoids, carotenoids, gingeroles, phytoestrogens and vitamin $\mathrm{C}$ are the phytochemical constituents present in $\mathrm{it}^{[194]}$. In 2014, the anti-ulcerogenic effect of Z . officinale (Ginger) roots in rats was evaluated by Uz Zaman et al. using indomethacin induced gastric damage [210]. The ginger roots extract (200 and $400 \mathrm{mg} /$ $\mathrm{kg})$ significantly $(P \leq 0.001)$ inhibited the gastric damage induced by indomethacin. The percentage inhibition of gastric ulcers was $40.91 \%, 57.58 \%$ and $65.91 \%$ by 200 and $400 \mathrm{mg} / \mathrm{kg}$ of $Z$. officinalis and omeprazole respectively. The $400 \mathrm{mg} / \mathrm{kg}$ of aqueous extract of $Z$. officinalis was found to be more effective than $200 \mathrm{mg} / \mathrm{kg}$. The ginger roots extract has the potential to prevent the gastric damage resulting from indomethacin (NSAID) administration ${ }^{[210]}$.

\section{DISCUSSION AND CONCLUSION}

From this study, it is clear that medicinal plants have portentous role in healing ulcers. WHO reported that $75 \%$ of the world population in developing world depends on the botanical medicines for their basic healthcare needs. The medical research and commerce exploiting many valuable experiences from the oral health traditions because the plants are easily available at cheap rate and another very important advantage is, it has very lesser side effects when compared to the synthetic drugs. Plants containing secondary metabolites like alkaloids, flavanoids, terpenoids, tannins, phenolic compounds, glycosides, terpines, and resins have an important role in relieving ulcers. These compounds protect the gastric mucosa from lesions produced by various ulcer models and against different necrotic agents. Studies reported that its activity is due to antisecretory mechanisms by inhibiting $\mathrm{H}+/ \mathrm{K}+$ proton pump, decreasing histamine levels by preventing its release from gastric mucosa, cytoprotective action by increasing the mucosal blood flow, stimulating the synthesis of mucosubstances, bicarbonate secretion and also by increasing the prostaglandin levels. The antioxidant compounds found in plants like quercetin, gracinol, rutin, gallic acid, ellagic acid, $\beta$ sitosterol, babaloin, isobarbaloin, etc. also has an important role reducing ulcer. Most of the plant extract contains antioxidant compounds; it acts by scavenching the free radicles and there by protect the gastric muosa from free radicle induced membrane damage. Therefore, the combination of traditional and modern knowledge can produce better drugs for the treatment of peptic ulcer with fewer side effects.

\section{CONFLICT OF INTEREST}

There are no conflicts of interest.

\section{REFERENCES}

1. F. Barazandeh, A. Yazdanbod, F. Pourfarzi, S.G. Sepanlou, M. H. Derakhshan, R. Malekzadeh, Epidemiology of peptic ulcer disease: endoscopic results of a systematic investigation in Iran, Middle East J Dig Dis, 4 (2012) 90.

2. T. Khomenko, S. Szabo, X. Deng, H. Ishikawa, G.J. Anderson, G.D. Mclaren, Role of iron in the pathogenesis of cysteamine-induced duodenal ulceration in rats, Am J Physiol Gastrointest Liver Physiol, 296 (2009) G1277-G1286.

3. N.S. Vyawahare, V.V. Deshmukh, M.R. Godkari, V.G. Kagathara, Plants with anti-ulcer activity, Pharmacogn Rev, 3 (2009) 108-115.

4. F.P. Brooks, the pathophysiology of peptic ulcer disease, Dig Dis Sci, 30 (1985) 15S-29S.

5. J.C. Zapata-Colindres, S. Zepeda-G omez, L.A. Montano, E. Vasquez-Ballesteros, J. Villalobos, F. Valdovinos- Andraca. The association of Helicobacter pylori infection and nonsteroidal anti-inflammatory drugs in peptic ulcer disease. Can J Gastroenterol, 20 (2006) 277-280.

6. J.Y. Lau, Y. Sung, C. Hill, C. Henderson, C.W. Howden, D.C. Metz, Systematic review of the epidemiology of complicated peptic ulcer disease: incidence, recurrence, risk factors and mortality, Digestion, 84 (2011) 102-113.

7. https://www.worldlifeexpectancy.com/india-pepticulcer-disease.

8. W.A. Hoogerwerf, P.J. Pasricha, Agents used for control of gastric acidity and treatment of peptic ulcers and gastro esophageal reflux disease, edition, pp. 1005-19, McGraw-Hill, New York, NY, USA, $10^{\text {th }}$ edition, 2001.

9. Z. Lima, J.A. Severi, C.H. Pellizon, A.R. Brito, P.N. Solis, A. Caceres, Can the aqueous decoction of mango flowers be used as an antiulcer agent?, J. Ethanopharmacol. 106 (2006) 29-37.

10. K. Harold, M. Grant Denis, J. Mitchel. Principles of medical pharmacology, 7 (2012) 557-559.

11. F. Borelli, A. Izzo, The plant kingdom as a source of anti-ulcer remedies, Phytother. Res. 14 (2000) $581-591$ 
12. G.F. Nascimento, J. Locatelli, P.C. Freitas, G.L. Silva, Antibacterial activity of plant extracts and phytochemicals on antibiotic resistant bacteria, Braz. J. Microbiol. 31 (2000) 247-256.

13. keralaplants.in/index.html

14. R.J. Luqman, Shahid-ul-Islam, M. Faqeer, Acacia nilotica (L.): A review of its traditional uses, phytochemistry, and pharmacology, Sustainable Chem Pharm, (2015) 1-19.

15. A.A. Dafallah, Z. Al-Mustafa, Investigation of the antiinflammatory activity of Acacia nilotica and Hibiscus sabdariffa. Am. J. Chin. Med. 24 (1996) 263-269.

16. B. Sultana, F. Anwar, R. Przybylski, 2007.Antioxidant activity of phenolic com- ponents present in barks of Azadirachta indica, Terminalia arjuna, Acacia nilotica, and Eugenia jambolana Lam. Trees, Food Chem.104 (2007). 1106-1114.

17. A. Misar, R. Bhagat, A.M. Mujumdar, Antidiarrhoeal activity of Acacia nilotica Wild. Bark methanol extract, Hindustan Antibiot. Bull. 50 (2008) 14-20.

18. A.H. Gilani, F. Shaheen, M. Zaman, K.H. Janbaz, B.H. Shah, M.S. Akhtar. Studies on antihypertensive and antispasmodic activities of methanol extract of Acacia nilotica pods, Phytother. Res.13 (1999) 665-669.

19. P. Rani, N. Khullar, Antimicrobial evaluation of some medicinal plants for their anti-enteric potential against multi-drug resistant Salmonella typhi, Phytother. Res. 18 (2004) 670-673.

20. H. Hostel, F. Jackson, S. Athanasiadou, S.M. Thamsborg, S.O. Hoskin, The effects of tannin-rich plants on parasitic nematodes in ruminants, Trends Parasitol. 22 (2006) 253-261.

21. O.J.M. Hamza, F.H.M. Mikx, A.O. Selemani, Z.H. Mbwambo, A.J.A.M. VanderVen, P.E. Verweij, Antifungal activity of some Tanzanian plants used traditionally for the treatment of fungal infections, $\mathrm{J}$. Ethnopharmacol.108 (2006) 124-132.

22. B.H. Shah, B. Safdar, S.S. Virani, Z. Nawaz, S.A. Saeed, A.H. Gilani, The antiplatelet aggregatory activity of Acacia nilotica is due to blockade of calcium influx through membrane calcium channels, Gen. Pharmacol. Vasc. Syst. 29 (1997) 251-255.

23. L.A. Alli, M.O. Nafiu, A.A. Adesokan, M.A. Akanji, A.Y. Tijani, O.A. Salawu, Antipyretic and analgesic activities of aqueous extract of Acacia nilotica root, Biokemistri 26, (2014) 55-62.
24. K. Asres, A. Seyoum, C. Veeresham, F. Buca, S. Gibbons, Naturally derived anti-HIV agents, Phytother. Res. 19 (2005) 557-581.

25. P.D. Meena, P. Kaushik, S. Shukla, A.K. Soni, M Kumar, A. Kumar, Anticancer and antimutagenic properties of Acacia nilotica (Linn.) on 7, 12 -Dimethyl benz(a)anthracene- induced skin papilloma genesis in Swiss Albino Mice. Asian Pac. J. Cancer Prev. 7 (2006) 627-632.

26. M. Asad, T.A. Munir, N. Afzal, Acacia Nilotica leaves extract and glyburide: comparison of fasting blood glucose, serum insulin, $\beta$-thromboglubulin levels and platelet aggregation in streptozotocin induced diabetic rats, J. Pak. Med. Assoc. 61 (2011) 247-251.

27. I.M.S. Eldeen, E.E. Elgorashi, J.V. Staden, Antibacterial, antiinflammatory, anti-cholinesterase and mutagenic effects of extracts obtained from some trees used in South African traditional medicine. J. Ethnopharmacol. 102 (2005) 457-464.

28. K.B. Vijay, K.G. Rajesh, Gastroprotective effect of Acacia nilotica young seedless pod extract: Role of polyphenolic constituents, Asian Pac. J. Tropical Medicine, (2012) 523-528.

29. K.D. Ashish, B. Papiya, K.V. Neelesh, A.C. Rana. Gastroprotective effect of Achyranthes aspera Linn. leaf on rats, Asian Pac. J. Tropical Medicine (2012)197-201.

30. C.C. Barua, A. Talukdar, S.A. Begum, L.C. Lahon, D.K. Sharma, D.C. Pathak, Antinociceptive activity of methanolic extract of leaves of $A$. aspera Linn. in animal model of nociception, Indian J. Exp. Biol. 48 (2010) 817-821.

31. M.S. Baliga, H.P. Bhat, N. Joseph, F. Fazal, Phytochemistry and medicinal uses of the bael fruit (Aegle marmelos Correa): a concise review, Food Res. Int. 44 (2011) 1768-75.

32. M. Bikash, R.P. Keshav, S. Biraj, K. Rajendra Phytochemical profile and pharmacological activity of Aegle marmelos Linn. J. Integr. Med. 16(3):153-163.

33. V. P. Reddy, A. Urooj, Antioxidant properties and stability of Aegle marmelos leaves extracts, J. Food Sci. Technol. 50 (2013)135-140.

34. T.H. Khan, S. Sultana, Antioxidant and hepatoprotective potential of Aegle marmelos Correa. against CCl4-induced oxidative stress and early tumor events. J. Enzyme Inhib. Med. Chem. 24 (2009) 320-327. 
35. P.V. Seema, B. Sudha, P.S. Padayatti, A. Abraham, K.G. Raghu, C.S. Paulose, Kinetic studies of purified malate dehydrogenase in liver of streptozotocindiabetic rats and the effect of leaf extract of Aegle marmelose (L.) Correa ex Roxb. Indian J. Exp. Biol. 34 (1996) 600-602.

36. S. Panda, A. Kar, Periplogenin-3-O--Dglucopyranosyl-( $1 \rightarrow 6)--D-$ glucopyaranosyl-$(1 \rightarrow 4)$-D-cymaropyranoside, isolated from Aegle marmelos protects doxorubicin induced cardiovascular problems and hepatotoxicity in rats, Cardiovasc. Ther. 27 (2009)108-116.

37. V. Arul, S. Miyazaki, R. Dhananjayan, Studies on the anti-inflammatory, antipyretic and analgesic properties of the leaves of Aegle marmelos, Corr. J. Ethnopharmacol. 96 (2005) 159-163.

38. P. Singh, A. Kumar, N.K. Dubey, R. Gupta R. Essential oil of Aegle marmelos as a safe plantbased antimicrobial against post-harvest microbial infestations and aflatoxin contamination of food commodities, J. Food Sci. 74 (2009) M302-7.

39. B.B. Mishra, N. Kishore, V.K. Tiwari, D.D. Singh, V. Tripathi. A novel antifungal anthraquinone from seeds of Aegle marmelos Correa (family Rutaceae), Fitoterapia, 81 (2010)104-107.

40. T. Narender, S. Shweta, P. Tiwari, R.K. Papi, T. Khaliq, P. Prathipati, Antihyperglycemic and antidyslipidemic agent from Aegle marmelos. Bio. Org. Med. Chem. Lett. 17 (2007)1808-1811.

41. I. Lampronti, D. Martello, N. Bianchi, M. Borgatti, E. Lambertini, R. Piva, In vitro antiproliferative effects on human tumor cell lines of extracts from the Bangladeshi medicinal plant Aegle marmelos Correa. Phytomed. 10 (2003) 300-308.

42. R. Sharmin, R.Q. Mohammad, S. Rayhana, M. Azmary, S. Khaleda, O.E. Eliza, Evaluation of antiulcer activity of ethanolic extract of Aegle marmelos leaves on rats, ARC J Dental Sci. 1(2016) 23-26.

43. R. Prasan, Bhandari, Garlic (Allium sativum L.): A review of potential therapeutic applications. Int. J. Green Pharm. (2012) 118-129.

44. C. Borek, Garlic reduces dementia and heart-disease risk, J. Nutr. 136 (2006) 810S-812S.

45. K.K. Al-Qattan, I. Khan, M.A. Alnaqeeb, M. Ali, Mechanism of garlic (Allium sativum) induced reduction of hypertension in $2 \mathrm{~K}-1 \mathrm{C}$ rats: $\mathrm{A}$ possible mediation of $\mathrm{Na} / \mathrm{H}$ exchanger isoform-1. Prostaglandins Leukot. Essent. Fatty Acids, 69 (2003) 217-222.

46. S. Brankovic, M. Radenkovic, D. Kitic, S. Veljkovic, V. Ivetic, D. Pavlovic, Comparison of the hypotensive and bradycardic activity of ginkgo, garlic, and onion extracts, Clin. Exp. Hypertens. 33 (2011) 95-99.

47. M. Budoff, Aged garlic extract retards progression of coronary artery calcification, J. Nutr. 136 (2006)741S-744S

48. M.S. Ahmad, N. Ahmed, Antiglycation properties of aged garlic extract: Possible role in prevention of diabetic complications, J. Nutr. 136 (2006) 796S-799S.

49. J.A. Milner, A historical perspective on garlic and cancer, J. Nutr. 131 (2001) 1027S-31S.

50. C. Borek, Antioxidant health effects of aged garlic extract, J. Nutr. 131 (2001)1010S-1015S.

51. C. Cruz, R. Correa-Rotter, D.J. Sanchez-Gonzalez, R. Hernández-Pando, P.D. Maldonado, C.M. Martinez-Martinez, Renoprotective and antihypertensive effects of S-allylcysteine in 5/6 nephrectomized rats. Am. J. Physiol. Renal Physiol. 293 (2007) 1691-16988.

52. E. Kyo, N. Uda, S. Kasuga, Y. Itakura, Immunomodulatory effects of aged garlic extract, J. Nutr. 131 (2001) 1075S-9S.

53. M. Arunachalam, S. Shailja, S. Krishnan, Ameliorative effects of Allilum sativum in pyloric ligation induced peptic ulcer in rat, Pharmacologia. 5 (2014) 256-262.

54. D.P. West, Y.F. Zhu, Evaluation of Aloe vera gel gloves in the treatment of dry skin associated with occupational exposure, Am. J. Infect. Control, 31 (2003) 40-42.

55. J. Madan, A. K. Sharma, N. Inamdar, H.S. Rao, R. Singh, Immunomodulatory properties of Aloe vera gel in mice, Int. J. Green Pharm. 2 (2008) 152-154.

56. J.P. Heggers, G.R Pineless, M.C. Robson, Dermaide aloe/Aloe vera gel: Comparison of the antimicrobial effects, Am. J. Med. Tech. 41 (1979) 293- 294.

57. R.J. Sydiskis, D.G. Owen, J.L. Lohr, K.H. Rosler, R.N. Blomster, Inactivation of enveloped viruses by anthraquinones extracted from plants, Antimicrob. Agents Chemother. 35 (1991) 2463-2466. 
58. Stanic S, Anti-genotoxic effect of Aloe vera gel on the mutagenic action of ethyl methanesulfonate, Arch. Biol. Sci. 59 (2007) 223-226.

59. S. Rajasekaran, K. Ravi, K. Sivagnanam, S. Subramanian, Beneficial effects of Aloe vera leaf gel extract on lipid profile status in rats with streptozotocin diabetes, Clin. Exp. Pharmacol. Physiol. 33 (2006) 232-237.

60. K.B. Sai, K.L. Radha, R.M. Gowrinath, Anti-ulcer effect of Aloe vera in non-steroidal anti-inflammatory drug induced peptic ulcers in rats, Afr. J. Pharm. Pharmacol. 5 (2011) 1867-1871.

61. S.Z. Moghadamtousi, M. Fadaeinasab, S. Nikzad, G. Mohan, Annona muricata (Annonaceae): a review of its traditional uses, isolated acetogenins and biological activities, Int. J. Mol. Sci. (2015) 15625-15658.

62. W. Solomon, Phytochemical screening and antimicrobial activities of Annona muricata (L.) leaf extract, Am. J. Biol. Chem. Pharm. Sci. 2 (2014) 1-7.

63. O.V. Sousa, G.D.V. Vieira, Antinociceptive and anti-inflammatory activities of the ethanol extract of Annona muricata L. leaves in animal models. Int. J. Mol. Sci. 11(2010) 2067-2078.

64. J.S. Luna, A.F. Dos Santos, M.R.F. De Lima, M.C. De Omena, F.C. De Mendonc, L.W. Bieber, A study of the larvicidal and molluscicidal activities of some medicinal plants from northeast Brazil, J. Ethnopharmacol. 97 (2005), 199-206.

65. G.A. Alitonou, F.P. Tchobo, P. Sessou, F. Avlessi, C. Menut, D.C.K. Sohounhloue, Chemical composition, antiradical and anti-inflammatory activities of four annonaceae from Benin, Int. J. Pharm. Chem. Biol. Sci. 3 (2013) 914-923.

66. V. Oviedo, M. Garcia, C. Diaz, M. Marder, M. Costa, J. Rincon, C. Sanchez, Extracto y fraccio' n alcaloidal de Annona muricata con actividad de tipo ansiolı'tica en ratones. Rev. Colomb Cienc. Qui'm. Farma. 38 (2009) 105-120.

67. S. Hamizah, A.H. Roslida, O. Fezah, K.L. Tan, Y.S. Tor, C.I. Tan, Chemopreventive potential of Annona muricata L. leaves on chemically-induced skin papilloma genesis in mice, Asian Pac. J. Cancer Prev. 13 (2012) 2533-2539.

68. A.H. Roslida, P.F. Chan, A. Zuraini, K.H. Mohd, Antinociceptive and anti-ulcerogenic activities of the ethanolic extract of Annona muricata leaf, Brazilian. J. Pharmacogn. 1 (2012) 1-12.
69. M.P. Padmaa, J.P.N., Chansouria, R.L., Khosa, Wound healing activity of Annona muricata extract, J. Pharm. Res. 2 (2009) 404- 406.

70. F.K. Arthur, E. Woode, E. Terlabi, C. Larbie, Bilirubin lowering potential of Annona muricata (Linn.) in temporary jaudiced rats, Am. J. Pharmacol. Toxicol. 7(2012) 33-40.

71. S.O. Adewole, E.A. Caxton-Martins, Morphological changes and hypoglicemic effects of Annona muricata Linn. (Annonaceae) leaf aqueous extract on pancreatic B-cells of Sreptozotocin-treated diabetic rats, Afr. J. Biomed. Res. 9 (2006) 173-187.

72. C.R. Nwokocha, D.U. Owu, A. Gordon, K. Thaxter, G. McCalla, R.I. Ozolua, L. Young, Possible mechanisms of action of the hypotensive effect of Annona muricata (soursop) in normotensive Sprague-Dawley rats. Pharm. Biol. 50 (2012) 1436-1441.

73. B.B. Elizangela, E.B.J. Francisco, R.O. Dayanne, N.F. Cicera, A.D. Gyllyandeson, R.A.S.C. Francisco, Antiulcerogenic activity of the hydroalcoholic extract of leaves of Annona muricata Linnaeus in mice, Saudi J. Bio. Sci. 25 (2018) 609-621.

74. J. G. Kashmira, A.P. Jagruti, A review on Bacopa monniera: Current research and future prospects. Int. J. Green Pharm. (2010) 1-9.

75. M.M. Sinha, Some empirical behavioural data indicative of concomitant biochemical reactions, Proceeds Ind. Sci. Congress Part II, (1971) 1-26.

76. S.K. Bhattacharya, A. Kumar, S. Ghosal, Effect of Bacopa monnieri on animal models of Alzheimer's disease and perturbed central cholinergic markers of cognition in rats, In: DV Siva Sankar, editors. Mol. Aspects Asian Med. (1999) 27-58.

77. Y.B. Tripathi, S .Chaurasia, E. Tripathi, A. Upadhyay, G.P. Dubey, Bacopa monniera Linn. as an antioxidant: mechanism of action, Ind. J. Exp. Biol. 34 (1996) 523-6.

78. K. Sairam, M. Dorababu, R.K. Goel, S.K Bhattacharya, Antidepressant activity of standardized extract of Bacopa monniera in experimental models of depression in rats, Phytomed. 9 (2002) 207-11.

79. G. Martis,A.Rao,K.S. Karanth, Neuropharmacological activity of Herpestis monniera. Fitoterapia, 63 (1992) 399- 404.

80. D. Rai, G. Bhatia, G. Palit, R. Pal, S. Singh, H. Singh, Adaptogenic effect of Bacopa monniera (Brahmi), Pharmacol. Biochem. Behav. 75 (2003) 823-30. 
81. S.K. Yadav, A.K. Jain, S.N. Tripathi, J.P. Gupta, Irritable bowel syndrome: therapeutic evaluation of indigenous drugs, Ind. J. Med. Res. 90 (1989) 496503.

82. K. Rubaba, F.K. Ashfia, A. Sabiha, S.S. Najia, T.M. Maliha, H. Nazmul, Evaluation of Antiulcerogenic activity of Bacopa Monnieri (LINN.) on ethanolinduced gastric injury in mice, Int. J. Innov. Res. Med. Sci. 3 (2018) $196-211$.

83. V. Tarun, P. Yash, A review on medicinal properties of Carica papaya Linn, Asian Pacific J. Trop. Dis. 5 (2015) 1-6.

84. E. Panzarini, M. Dwikat, S. Mariano, C. Vergallo, L. Dini, Administration dependent antioxidant effect of Carica papaya seeds water extract. Evid. Based Complement Alternat. Med. (2014) 281-508.

85. A.E. Eno, O.I. Owo, E.H. Itam, R.S. Konya, Blood pressure depression by the fruit juice of Carica papaya (L.) in renal and DOCA-induced hypertension in the rat, Phytother. Res. 14 (2000) 235-239.

86. L. Tona, K. Kambu, N. Ngimbi, K. Cimanga, A.J. Vlietinck, Antiamoebic and phytochemical screening of some Congolese medicinal plants, J. Ethnopharmacol. 61 (1998) 57-65.

87. I.I. Anibijuwn, A.O. Udeze, Antimicrobial activity of Carica papaya (pawpaw leaf) on some pathogenic organisms of clinical origin from South-Western Nigeria, Ethno. Leaflets. 13 (2009) 850-864.

88. R. Giordani, M. Siepaio, J. Moulin-Traffort, P. Regli, Antifungal action of Carica papaya latex, isolation of fungal cell wall hydrolyzing enzymes, Mycoses. 34 (1991) 469-477.

89. A. Adebiyi, P.G. Adaikan, R.N. Prasad, Histaminergic effect of crude papaya latex on isolated guinea pig ileal strips, Phytomed. 11 (2004) 65-70.

90. B. Sripanidkulchai, V. Wongpanich, P. Laupattarakasem, J. Suwansaksri, D. Jirakulsomchok, Diuretic effects of selected Thia indigenous medicinal plants in rats, J. Ethnopharmacol. 75 (2001) 185-190.

91. G. Rimbach, Y.C. Park, Q. Guo, H. Moini, N. Qureshi, C. Sauliou, Nitric oxide synthesis and TNF-alpha secretion in RAW264.7 macrophages: mode of action of a fermented papaya prepration, Life Sci. 67 (2000) 679-694.

92. N. Otsuki, N.H. Dang, E. Kumagai, A. Kondo, S. Iwata, C. Morimoto, Aqueous extract of Carica papaya leaves exhibits anti-tumor and immunomodulatory effects, J. Ethnopharmacol. 127 (2010) 760- 767.

93. M.K. Krishnakumari, S.K. Majumder, Studies on anthelmintic activities of seeds of Carica papaya Linn. Ann. Biochem. Exp. Med. 20 (1960) 551-556.

94. G.P. Bhat, N. Surolia, In vitro Antimalarial activity of extracts of the three plants used in the tradtitional medicine of India, Am. J. Trop. Hyg. 65 (2001) 304-308.

95. T.O. Fekeye, T. Oladipupo, O. Showande, Y. Ogunremi, Effects of co-adminstration of extract of Carica papaya on activity of two oral hypoglycemic agents, Trop. J. Pharm. Res. 6 (2007) 671-678.

96. A.O. Tolunigba, W.O. Adekunle, Gastroproctective activity of aqueous Carica papaya seed axtract on ethanol induced gastric ulcer in male rats, Afr. J. Biotechnol. 11 (2012) 8612- 8615.

97. N.O.A. Imaga, G.O. Gbenle, V.I. Okochi, S.O. Akanbi, S.O. Edeoghon, V. Oigbochie, Antisickling property of Carica papaya leaf extract, Afr. J. Biochem. Res. 3 (2009) 102-106.

98. K. Ramandeep, S. Kalyan, Antiulcer activity of hydroalcoholic extract of unripe fruit of Carica papaya in experimental rats, Int. J. Basic Clin. Pharmacol. 6 (2017) 432- 440

99. D. Arora, M. Kumar, S. D. Dubey. Centella asiatica - a review of its medicinal uses and pharmacological effects. J. Nat. Remedies. 2 (2002) 143-149.

100. F.X. Maquart, G. Bellon, P. Gillery, Y. Wegrowski, J.P. Borel, Stimulation of collagen synthesis in fibroblast cultures by triterpenes extracted from C. asciatica, Connect. Tiss. Res. 24 (1990) 107-120.

101. M.K. Zaunol, A. Abd-Hamid, S. Yusof, R. Muse, Antioxidative activity and total phenolic compounds of leaf, root and petiole of four accessions of C. asiatica L. Urban. Food. Chem. 81 (2003) 575-581.

102. C.L. Cheng, J.S. Guo, J. Luk, M.W. Koo, The healing effects of centella extract and asiaticoside on acetic acid induced gastric ulcer in rats, Life. Sci. 74 (2004) 2237-2249.

103. B.C. Park, K.O. Bosire, E.S. Lee, Y.S. Lee, J.A. Kim, Asiatic acid induces apoptosis in SK-MEL-2 human melanoma cells. Cancer. Lett. 218 (2005) 81-90.

104. M.R. Zaidan, R.A. Noor, A.R. Badrul, A. Adlin, A. Norazah, I. Zakiah, In vitro screening of five local 
medicinal plants for antibacterial activity using diffusion method, Trop. Biomed. 22 (2005) 165-170.

105. J.S. Guo, C.L. Cheng, M.W. Koo, Inhibitory effects of C. asiatica water extract and asiaticoside on inducible nitric oxide synthase during gastric ulcer healing in rats, Planta. Medica. 70 (2004) 1150-1154.

106. M. A. Abdulla, F. H. AL-Bayaty, L. T. Younis, M. I. Abu Hassan, Anti-ulcer activity of Centella asiatica leaf extract against ethanol-induced gastric mucosal injury in rats, J. of Med. Plants Rese. 4 (2010). 12531259.

107. A. Kamran, S. Sadia, A comprehensive review on Curcuma longa Linn.: Phytochemical, pharmacological, and molecular study. Int. J. Green Pharm. 2017; 11 (4): S671- S685.

108. R. Srivastava, R.C. Srimal, Modification of certain inflammation-induced biochemical changes by curcumin, Indian J. Med. Res. 81 (1985) 215-223.

109. O.P. Sharma, Antioxidant activity of curcumin and related compounds, Biochem. Pharmacol. 25 (1976) 1811-2.

110. S. Somasundaram, N.A. Edmund, D.T. Moore, G.W. Small, Y.Y. Shi, R.Z. Orlowski, Dietary curcumin inhibits chemotherapy-induced apoptosis in models of human breast cancer. Cancer Res. 62 (2002) 3868-75.

111. R. Srivastava, M. Dikshit, R.C. Srimal, B.N. Dhawan, Anti-thrombotic effect of curcumin, Thromb. Res. 40 (1985) 413-7.

112. N. Arun, N. Nalini, Efficacy of turmeric on blood sugar and polyol pathway in diabetic albino rats, Plant Foods Hum. Nutr. 57 (2002) 41-52.

113. S. Ungphaiboon, T. Supavita, P. Singchangchai, S. Sungkarak, P. Rattanasuwan, A. Itharat, Study on antioxidant and antimicrobial activities of turmeric clear liquid soap for wound treatment of HIV patients, Songklan J. Scitech. 27 (2005)269-578.

114. R.S. Upendra, P. Khandelwal, A.H. Reddy, Turmeric powder (Curcuma longa Linn.) as an antifungal agent in plant tissue culture studies, Int. J. Eng. Sci. 3 (2011) 7899-904.

115. S. Barthelemy, L. Vergnes, M. Moynier, D. Guyot, S. Labidalle, E. Bahraoui, Curcumin and curcumin derivatives inhibit Tat-mediated transactivation of Type 1 human immunodeficiency virus long terminal repeat, Res. Virol. 149 (2008)43-52.
116. K.A.A. Karolin, Comparative evaluation of the antiulcer activity of curcumin and omeprazole during the acute phase of gastric ulcer, Food and Nutri. Sci. 2 (2011) 628-640.

117. Mehjabeen, A. Mansoor, Noorjahan, Farah-Saeed, B.R. Asif, The role of elettaria cardamomum (1.) maton in inflammatory, gastrointestinal and stress disorders, Int. J. Pharm. Phytopharmacol. Res. 4 (2015) 302-305.

118. A. Jamal, J. Kalim, M. Aslama, M.A. Jafri, Gastroprotective effect of cardamom, Elettaria cardamomum Maton. fruits in rats, J. Ethnopharmacol. 103 (2006) 149-153.

119. V.M. Jadhav, R.M. Thorat, V.J. Kadam, N. S. Sathe. Traditional medicinal uses of Hibiscus rosa-sinensis. J. Pharm. Res. 2 (2009) 1220-1222.

120. C.M. Reddy, D.R. Murthy, S.B. Patil, Antispermatogenic and androgenic activities of various extracts of Hibiscus rosa sinensis in albino mice, Indian J. Exp. Biol. 35 (1997) 1170-4.

121. E. Serrame, S.C.Y. Lim, Antitumour promoting activity of decoctions and expressed juices from Philippine medicinal plants, Philipine J. Sci. 124 (1995) 275-81

122. V.S. Kasture, C.T. Chopde, V.K. Deshmukh, Anticonvulsive activity of Albizzia lebbeck, Hibiscus rosa sinensis and Butea monosperma in experimental animals, J. Ethnopharmacol. 71 (2000) 65-75.

123. M.M. Alam, M.B. Siddiqui, W. Hussai, Treatment of diabetes through herbal drugs in rural India, Fitoterapia. 61 (1990)240-2.

124. S. Srivastava, J. Jaiswal, H. Gautam, S. Sharma, C.H. $\mathrm{V}$. Rao, anti-ulcer activity of methanolic extract of Hibiscus rosa Sinensis leaves, Int. J. Pharm. Pharm. Sci. 5 (2013) 829-830.

125. M. Ali, S.H. Ansari. Hair care and herbal drugs, Ind. J. Nat. Prods. 13 (1997) 3-5.

126. K.E. Meran, H.T. Kamani, R.S. Sameera, A Review on Ethnopharmacological Applications, Pharmacological Activities, and Bioactive Compounds of Mangifera indica (Mango), Evi.-Bas. Compl. and Alt. Med. (2017) 1-24.

127. Prabhu, M. K. M. Krishnamoorthy, D. J. Prasad, P. Naik, Anticancer activity of friedelin isolated from ethanolic leaf extract of Cassia tora on HeLa and HSC-1 cell lines, Ind. J. Appl. Res. 3(2011) 1-4. 
128. L. Marquez, B.G. Perez-Nievas, I. Garate, Antiinflammatory effects of Mangifera indica L. extract in a model of colitis, World J Gastroenterol. 16, (2010) 4922-4931.

129. Ganogpichayagrai, C. Palanuvej, N. Ruangrungsi, Antidiabetic and anticancer activities of Mangifera indica cv. Okrong leaves, J. Adv. Pharm. Technol. Res. 8 (2017)19-24.

130. J. K. Mutua, S. Imathiu, W. Owino, Evaluation of the proximate composition, antioxidant potential, and antimicrobial activity of mango seed kernel extracts, Food Sci. Nutr. 5 (2017) 349-357.

131. P. Alok, V. Keerthana, J. C. Kumar, K. Ratan, A. D. Chand, Antibacterial property of two different varieties of Indian mango (Mangifera indica) kernel extracts at various concentrations against some human pathogenic bacterial strains, Res. J. Bio. Sci. 2 (2013) $28-32$.

132. E. Dorta, M. Gonzalez, M. G. Lobo, F. Laich, Antifungal activity of mango peel and seed extracts against clinically pathogenic and food spoilage yeasts, Nat. Pro. Res. 30 (2016) 2598- 2604.

133. D. Garcia, M. Escalante, R. Delgado, F. M. Ubeira, and J. Leiro, Anthelminthic and antiallergic activities of Mangifera indica L. stem bark components vimang and mangiferin, Phytother. Res. 17 (2003)1203-1208.

134. J. A. Severi, Z. P. Lima, H. Kushima et al., Polyphenols with antiulcerogenic action from aqueous decoction of mango leaves (Mangifera indica L.), Molecules, 14 (2009) 1098-1110.

135. J. Pourahmad, M. R. Eskandari, R. Shakibaei, M. Kamalinejad, A search for hepatoprotective activity of fruit extract of Mangifera indica L. against oxidative stress cytotoxicity, Plant Food Hum. Nutr. 65 (2010). 83-89.

136. N.Makare, S. Bodhankar, V. Rangari, Immunomodulatory activity of alcoholic extract of Mangifera indica L. in mice, J Ethnopharmacol. 78 (2001) 133-137.

137. G. T. El-Sherbini, S. M. Osman, Anthelmintic activity of unripe Mangifera indica L. (Mango) against Strongyloides stercoralis, Int. J. Curr. Microbiol. Applied Sci. 2 (2013) 401-409.

138. M. Heng, Z. Lu, Antiviral effect of mangiferin and isomangiferin on herpes simplex virus, Chinese Med. J. 103 (1990) 160-165.
139. R. A. Vasant, A. V. R. L. Narasimhacharya Antihyperglycemic and Antihyperlipemic effects of Mangifera indica L. in fluoride induced toxicity, Pharmacologyonline, 3 (2011) 265- 274.

140. K. Prabhu, S. Rajan, Assessment of Antiulcer Activity of Ethanolic Extract of Mangifera indica Seed Kernel Using Acid Ethanol Induced Ulcer Model, Int. J. Curr. Microbiol. App. Sci. 4 (2015) 854-860.

141. G. Vinothapooshan, K. Sundar, Anti-ulcer activity of Mimosa pudica leaves against gastric ulcer in rats, Res. J. Pharm. Biol. Chem. Sci. 1 (2010) 606-614.

142. V. Elango, O. Carolin, P.S. Raghu, Antiulcer activity of the Leaf ethanolic extract of Mimosa pudica in Rats, Hygeia. J. D. Med. 4 (2012) 34-40.

143. M. Daba, Miracle Tree: A Review on Multi-purposes of Moringa oleifera and Its Implication for Climate Change Mitigation, J. Earth Sci. Clim. Change, 8 (2016) 1-5.

144. S. Nair, K.N. Varalakshmi, Anticancer, cytotoxic potential of Moringa oleifera extracts on HeLa cell line, J. Nat. Pharm. 2 (2011) 138-142.

145. V.I. Hukkeri, C.V. Nagathan, R.V. Karandi, B.S. Patil, Antipyretic and wound healing activities of Moringa oleifera Lam in rats. Indian J. Pharm. Sci. 68 (2006) 124-126.

146. C.V. Rao, S.K. Ojha, Analgesic effect of Moringa oleifera Lam leaves extract on rats, Second World Congress on Biotechnological Developments of Herbal Medicine, Lucknow: NBRI, (2003) 42.

147. J.W. Fahey, Moringa oleifera: a review of the medical evidence for its nutritional, therapeutic, and prophylactic properties, Trees for Life J. 80 (2005) $1-5$.

148. A.V. Rao, P.U. Devi, R. Kamath, In vivo radioprotective effect of Moringa oleifera leaves. Ind. J. Exp. Biol, 39 (2001) 858-863.

149. D. Selvakumar, P. Natarajan, Hepatoprotective activity of Moringa oleifera Lam leaves in carbon tetrachloride induced hepatotoxicity in albino rats, Phcog. Mag. 4 (2008) 97- 98.

150. K.C. Manoj, H. Surendra, K.G. Sanjay, Assessment of the Antiulcer Potential of Moringa oleifera RootBark Extract in Rats. J. Acupunct. Meridian Stud. 6 (2013) 214-220. 
151. P. Pattanayak, B. Pritishova, D. Debajyoti, K. Sangram, Panda, Ocimum sanctum Linn. A reservoir plant for therapeutic applications: An overview, Pharmacogn. Rev. 4 (2010) 96- 105.

152. S.K. Gupta, J. Prakash, S. Srivastav, Validation of traditional claim of Tulsi, Ocimum sanctum Linn. as a medicinal plant, Indian J. Exp. Biol. 40 (2002) 765-73.

153. M. Sharm, K. Kishore, S.K. Gupta, S. Joshi, D.S. Arya, Cardioprotective potential of Ocimum sanctum Linn in isoproterenol induced myocardial infraction in rats, Mol. Cell Biochem. 498 (2001) 39-46.

154. Shetty S, Udupa S, Udupa L, Somayaji N. Wound healing activity of Ocimum sanctum Linn with supportive role of antioxidant enzymes. Indian J. Physiol. Pharmacol. 50 (2006) 163-8.

155. U.S. Bhartiya, Y.S. Raut, L.J. Joseph, Protective effect of Ocimum sanctum L after high-dose 131iodine exposure in mice: An in vivo study, Indian J. Exp. Biol. 44 (2006) 647-52.

156. P. Dharmani, V.K. Kuchibhotla, R. Maurya, S. Srivastava, S. Sharma, G. Patil, Evaluation of antiulcerogenic and ulcer healing properties of Ocimum sanctum Linn, J. Ethnophamacol. 93 (2004)197-206.

157. S. Singh, M. Malhotra, D.K. Majumdar, Antibacterial activity of Ocimum sanctum L. fixed oil, Indian J. Exp. Biol. 43 (2005) 835-7.

158. P.K. Mediratta, K.K. Sharma, S. Singh, Evaluation of immunomodulatory potential of Ocimum sanctum seed oil and its possible mechanism of action, J. Ethnopharmacol. 80 (2002) 15-20.

159. S. Godhwani, J.L. Godhwani, D.S. Vyas, Ocimum sanctum: A preliminary study evaluating its immunoregulatory profile in albino rats, J. Ethnopharmacol. 24 (1988) 193-8.

160. P. Shokeen, K. Ray, M. Bala, V. Tondon, Prelimnary studies on activity of Ocimum sanctum, Drynaria quercifolia, and Annona squamosa against Neisseria gonorrohoeae. Sex Transm. Dis. 32 (2005) 106-11.

161. M. Ahmed, R.N. Ahamed, R.H. Aladakatti, M.G.Ghosesawar, Reversible anti-fertility effect of benzene extract of Ocimum sanctum leaves on sperm parameters and fructose content in rats, J. Basic Clin. Physiol. Pharmacol. 13 (2002)51-59.

162. M.K. Asha, D. Prashanth, B. Murali, R. Padmaja, A. Amit, Anthelmintic activity of essential oil of Ocimum sanctum and eugenol, Fitoterapia. 72 (2001)669-70.
163. K. Karthikeyan, P. Ravichandran, S. Govindasamy, Chemo preventive effect of Ocimum sanctum on DMBA-induced hamster buccal pouch carcinogenesis, Oral Oncol. 35 (1999) 112-9.

164. S. Panda, A. Kar, Ocimum sanctum leaf extract in the regulation of thyroid function in the male mouse, Pharmacol. Res. 38 (1998) 107-10.

165. B.M. Bharat, C.D. Mangala, C.D. Subas, K. E. V. Nagojia, Anti-ulcer activity of aqueous and ethanolic leaf extract of tulasi (ocimum sanctum) in albino rats, J. Pharm. Res. 5 (2012) 4060-4062.

166. Z.A. Damanhouri, A. Ahmad, A Review on Therapeutic Potential of Piper nigrum L. (Black Pepper): The King of Spices, Medicinal \& Aromatic Plants. Med. Aromat. Plants, 3 (2014) 1-6.

167. S.I. Taqvi, A.J. Shah, A.H. Gilani, Blood pressure lowering and vaso modulator effects of piperine, $\mathrm{J}$ Cardiovasc. Pharmacol. 52 (2008) 452-458.

168. N. Ahmad, H. Fazal, B.H. Abbasi, S. Farooq, M. Ali, Biological role of Piper nigrum L. (Black pepper): A review, Asian Pacific J. Trop. Biomed. (2012) S1945-S1953

169. E.S. Sunila, G. Kuttan, Immunomodulatory and antitumor activity of Piper longum Linn. and piperine, J. Ethnopharmacol. 90 (2004) 339-346.

170. R. Parganiha, S. Verma, S. Chandrakar, S. Pal, H.A. Sawarkar, P. Kashyap, In vitro anti- asthmatic activity of fruit extract of Piper nigrum (Piperaceae). Inter. J. Herbal Drug Res. 1 (2011)15-18.

171.[171] I.A. Bukhari, N. Pivac, M.S. Alhumayyd, A.L. Mahesar, A.H. Gilani, The analgesic and anticonvulsant effects of piperine in mice, J. Physiol. Pharmacol. 64 (2013) 789-794.

172. J.S. Bang, H. Oh da, H.M. Choi, B.J. Sur, S.J. Lim, Anti-inflammatory and antiarthritic effects of piperine in human interleukin 1beta-stimulated fibroblast-like synoviocytes and in rat arthritis models, Arthritis Res. Ther. 11 (2009) R49.

173. P.B. Shamkuwar, S.R. Shahi, S.T. Jadhav, Evaluation of antidiarrhoeal effect of Black pepper (Piper nigrum L), Asian J. Plant Sci. Res. 2 (2012) 48-53.

174. S. Li, C. Wang, M. Wang, W. Li, K. Matsumoto, Antidepressant like effects of piperine in chronic mild stress treated mice and its possible mechanisms, Life Sci. 80 (2007) 1373- 1381 
175. H. Matsuda, K. Ninomiya, T. Morikawa, D. Yasuda, I. Yamaguchi, Protective effects of amide constituents from the fruit of Piper chaba on D-galactosamine/ TNF-alpha-induced cell death in mouse hepatocytes, Bioorg. Med. Chem. Lett. 18 (2008)2038-2042.

176. K.P. Kumar, G. Gnanajobitha, M. Vanaja, S.R. Kumar, C. Malarkodi, K. Pandian, Piper nigrum leaf and stem assisted green synthesis of silver nanoparticles and evaluation of its antibacterial activity against agricultural plant pathogens. Sci. World J. (2014) 829-894

177. J. Wattanathorn, P. Chonpathompikunlert, S. Muchimapura, A. Priprem, O. Tankamnerdthai, Piperine, the potential functional food for mood and cognitive disorders, Food Chem.Toxicol. 46 (2008) 3106-3110.

178. J.J. Johnson, M. Nihal, I.A. Siddiqui, C.O. Scarlett, H.H. Bailey, Enhancing the bioavailability of resveratrol by combining it with piperine, Mol. Nutr. Food Res. 55 (2011)1169-1176.

179. H.A. Muna, study the effect of Aqueous Extract of Piper nigrum on Some physiological parameters and Histopathological in Female Rabbit Induced Gastric Ulceration by Aspirin. J. Kerbala Uni, 12 (2014) 19-32.

180. A. Bhattacharya, S. Ghosal, S.K. Bhattacharya, Antioxidant activity of tannoid principles of Emblica officinalis (amla) in chronic stress induced changes in rat brain. Indian J. Exp. Biol. 38 (2000) 87780.

181. C. Ngamkitidechakul, K. Jaijoy, P. Hansakul, N. Soonthornchareonnon, S. Sireeratawong, Antitumour effects of Phyllanthus emblica L.: Induction of cancer cell apoptosis and inhibition of in vivo tumour promotion and in vitro invasion of human cancer cells, Phytother. Res. 24 (2010)1405-13.

182. S. Kaur, S. Arora, K. Kaur, S. Kumar, The invitroantimutagenic activity of Triphala--an Indian herbal drug, Food Chem. Toxicol. 40 (2002) 527-534.

183. M.Z. Asmawi, H. Kankaanranta, E. Moilanen, H. Vapaatalo, Anti-inflammatory activities of Emblica officinalis Gaertn leaf extracts. J. Pharm. Pharmacol. 45 (1993)581-4.

184. M.S. Akhtar, A. Ramzan, A. Ali, M. Ahmad, Effect of Amla fruit (Emblica officinalis Gaertn.) on blood glucose and lipid profile of normal subjects and type 2 diabetic patients, Int. J. Food Sci. Nutr. 62 (2011) 609-16.
185. D. Dhingra, P. Joshi, A. Gupta, R. Chhillar, Possible involvement of monoaminergic neurotransmission in antidepressant-like activity of Emblica officinalis fruits in mice, CNS Neurosci. Ther. 18 (2012) 419-25.

186. K. Sairam, V. Rao Ch, M.D. Babu, K.V. Kumar, V.K. Agrawal, R.K. Goel, Antiulcerogenic effect of methanolic extract of Emblica officinalis: An experimental study, J. Ethnopharmacol. 82 (2002) 1-9.

187. M. Sumitra, P. Manikandan, V.S. Gayathri, P Mahendran, L. Suguna, Emblica officinalis exerts wound healing action through up-regulation of collagen and extracellular signal-regulated kinases (ERK1/2), Wound Repair Regen. 17 (2009) 99-107.

188. K.A. Head, Natural therapies for ocular disorders, part two: Cataracts and glaucoma, Altern. Med. Rev. 6 (2001) 141-66.

189. S.S. Patel, R.K. Goyal, Prevention of diabetes-induced myocardial dysfunction in rats using the juice of the Emblica officinalis fruit. Exp. Clin. Cardiol. 16 (2011) 87-91.

190. A.P. Kulkarni, L.A. Kellaway, G.J. Kotwal, Herbal complement inhibitors in the treatment of neuroinflammation: Future strategy for neuroprotection, Ann. N. Y. Acad. Sci. 1056 (2005) 413-429.

191. S. Joshy, Shirish, V. Snehalata, Gajbhiye, T. Urmila, Evaluation of gastric motility of Phyllanthus emblica and Asparagus racemosus in cold stress induced gastric damage, Int. J. Basic Clin. Pharmacol. 5 (2016) 1516- 1519.

192. D. Raju, K. Ilango, V. Chitra, K. Ashish, Evaluation of Anti-ulcer activity of methanolic extract of Terminalia chebula fruits in experimental rats, J. Pharm. Sci. Res. 1(2009) 101-107.

193. R.R. Chattopadhyay, S.K. Bhattacharyya, Plant Review Terminalia chebula: An Update, Pharmacog. Rev. 1 (2007) 151-156.

194. D. Jyotsna, A. Neelam, N. Viveka, A Review on Zingiber officinale, J. Pharma. Phytochem. 6 (2017) 174-184.

195. I.N. Chen, C.C. Chang, C.C. Ng, C.Y. Wang, Y.T. Shyu, T.L. Chang, antioxidant and antimicrobial activity of zingiberaceous plants in Taiwan, Plants Foods Hum. Nutr. 63 (2008) 15-20.

196. H. Ling, H. Yang, S.H. Tan, W.K. Chui, E.H. Chew, 6- Shogaol, an active constituent of ginger, inhibits 
breast cancer cell invasion by reducing matrix metalloproteinase-9 expression via blockade of nuclear factor- $\mathrm{kB}$ activation, Br. J. Pharmacol. 161 (2010) 1763-77.

197. S.P. Akhani, S.L. Vishwakarma, R.K. Goyal, Anti-diabetic activity of Zingiber officinale in streptozotocin-induced type I diabetic rats. J.Pharm Pharmacol. 56 (2004) 101-105.

198. M. Thomson, K.K. Al-Qattan, S.M. Al-Sawan, M.A. Alnaqeeb, I. Khan, M. Ali, The use of ginger (Zingiber officinale Rosc.) as a potential anti-inflammatory and antithrombotic agent. Prostaglandins Leukot. Essent. Fatty Acids, 67 (2002) 475-478.

199. T. Onogi, M. Minami, Y. Kuraishi, M. Satoh, Capsaicin-like effect of (6)-shogaol on substance P-containing primary afferents of rats: a possible mechanism of its analgesic action. Neuropharmacol. 31 (1992) 1165-1169.

200. N. Mascolo, R. Jain, S.C. Jain, F. Capasso, Ethnopharmacologic investigation of ginger (Zingiber officinale). J. Ethnopharmacol.27 (1989) 129-140.

201. C. Wilasrusmee, J. Siddiqui, D. Bruch, S. Wilasrusmee, S. Kittur, D.S. Kittur, In vitro immunomodulatory effects of herbal products. Am. Surg. 68 (2000) 860864.

202. Y.R. Liao, Y.L. Leu, Y.Y. Chan, P.C. Kuo, T.S. Wu. Antiplatelet aggregation and vasorelaxing effects of the constituents of the rhizomes of Zingiber officinale, Molecules. 17 (2012) 8928-8937.

203. E.C. Kim, J.K. Min, T.Y. Kim, S.J. Lee, H.O. Yang, S. Han, [6]-Gingerol, a pungent ingredient of ginger, inhibits angiogenesis in vitro and in vivo. Biochem. Biophys. Res. Commun. 335 (2005) 300-308.

204. A.A. Khaki, A. Khaki, Antioxidant effect of ginger to prevents lead-induced liver tissue apoptosis in rat, J. Med. Plants Res. 4 (2010) 1492-1495.

205. A.B. Lumb. Mechanism of antiemetic effect of ginger, Anaesthesia. 48 (1993) 1118.

206. S.K. Ha, E. Moon, M.S. Ju, D.H. Kim, J.H. Ryu, M.S. Oh, 6-Shogaol, a ginger product, modulates neuro inflammation: a new approach to neuroprotection, Neuropharmacol. 63 (2012) 211-23.

207. Z. Iqbal, Q.K. Nadeem, M.N. Khan, M.S. Akhtar, F.N. Waraich, in vitro anthelmintic activity of Allium sativum, Zingiber officinale, Curcurbita mexicana and Ficus religiosa, Int. J. Agri. Biol. 3 (2001) 454-457.
208. J. Yamahara, M. Mochizuki, H.Q. Rong, H. Matsuda, H. Fujimura, The anti-ulcer effect in rats of ginger constituents, J. Ethnopharmacol. 23 (1988) 299-304.

209. M.N. Ghayur, A.H. Gilani, Ginger lowers blood pressure through blockade of voltage dependent calcium channels. J Cardiovasc Pharmacol. 45 (2005) 74- 80 .

210. U.Z. Sameer, M.M. Mrutyunjay, S. Ramabhimaiah, Evaluation of the anti-ulcerogenic effect of Zingiber officinale (Ginger) root in rats, Int. J. Curr. Microbiol. App. Sci. 3 (2014) 347-354.

211. R. Prabjone, Thong-Ngam, N. Wisedopas, T. Chatsuwan, S. Patumraj, Anti-inflammatory effects of Aloe vera on leukocyte-endothelium interaction in the gastric microcirculation of Helicobacter pyloriinfected rats. Clin. Hemorheol. Microcirc. 35 (2006) 359-366.

212. B.B. Hoffman, $\mathrm{Fa}^{\prime}$ rmacos antagonistas dos adreno receptores. In: Katzung, B.G. (Ed.), Farmacologia ba' sica e cli'nica, tenth ed. McGraw-Hill, Sa o Paulo, (2007) 127-141.

213. K. Sairam, Ch.V. Rao, M. Dora Babu, K. Vijay Kumar, V.K. Agrawal, R. K. Goel, Antiulcerogenic effect of methanolic extract of Emblica officinalis: an experimental study, J. Ethnopharmacol. 82 (2002) $1-9$.

214. K. Nethravathi, M. S. Chandrashekhar, T. A. Siddique, G. Lakshminarayana, Evaluation of antiulcer activity of Mangifera indica kernel, vitamins and zinc sulphate on pylorus ligation and ethanol induced ulcer models in rats, Int. J. Phytopharmacol. 6 (2015) 86-97.

215. J. A. Severi, Z. P. Lima, H. Kushima, Polyphenols with antiulcerogenic action fromaqueous decoction of mango leaves (Mangifera indica L.), Molecules, 14 (2009)1098-1110.

216. U.Z. Sameer, M. Mrutyunjay, Mirje, S. Ramabhimaiah, Evaluation of the anti-ulcerogenic effect of Zingiber officinale (Ginger) root in rats. Int. J. Curr. Microbiol. App. Sci. 3 (2014) 347-354.

217. M. Khushtar, V. Kumar, K. Javed, Uma Bhandari Protective effect of ginger oil on aspirin and pylorus ligation-induced gastric ulcer model in rats. Indian J. Pharm. Sci. 71 (2009) 554-558.

218. M.N. Siddaraju, N.M. Harish, M.D. Shylaja, Gastroprotective effect of ginger rhizome (Zingiber officinale) extract: Role of gallic acid and cinnamic acid in $\mathrm{H}^{+} \mathrm{K}^{+}$-ATPase/H. pylori inhibition and anti-oxidative mechanism. eCAM, Oxford Journals: (2010) 8:24. 